POLIICALECONOMY RESARCH INSTIUIE

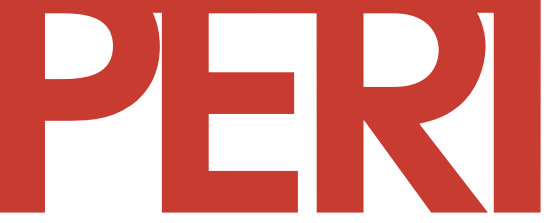

University of Massac husetts Amherst

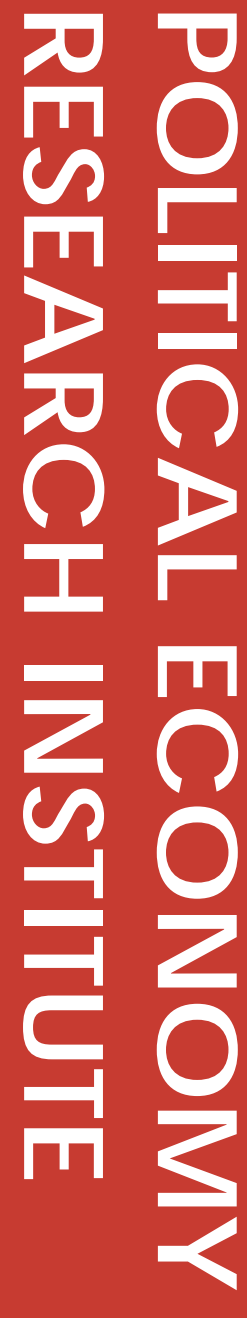

Léonce Ndikumana

2001

10th floor Thompson Hall

University of Massachusetts

Amherst, MA, 01003-7510

Telephone: (413) 545-6355

Facsimile: (413) 545-2921

Emailpperi@ec onsumassedu Whasite:

htp:// wmw.umassedu/peil/

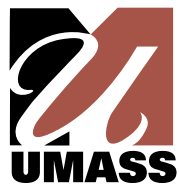




\title{
Financial Markets and Economic Development in Africa
}

\author{
Léonce Ndikumana \\ Department of Economics and \\ Political Economy Research Institute \\ University of Massachusetts \\ Amherst, MA 01003 \\ Tel: (413) 545-6359 \\ Fax: (413) 545-2921 \\ Email:ndiku@econs.umass.edu \\ Web: http://www-unix.oit.umass.edu/ ndiku
}

This draft: May 2001

\section{Acknowledgements:}

The author is grateful for funding from the Ford Foundation and the Political Economy Research Institute (PERI) at the University of Massachusetts. He also appreciates comments from participants at the PERI international workshop on "Finance and Investment" organized on October 27-28, 2000 at the University of Massachusetts. Jane D'Arista, Mark Brenner, and three anonymous reviewers provided helpful comments on an earlier draft of this manuscript. Research assistance from Lawrance Evans is very well appreciated. 
A machine cannot operate satisfactorily without lubricants... Metaphorically, finance is the lubricant of the process of economic growth, and the banking system is the chief dispenser of finance. (Cameron et al 1967: 2)

\section{Introduction}

The role of financial markets in economic development continues to attract increasing attention both in academia and among policy-makers. ${ }^{1}$ Evidence from recent empirical studies suggests that deeper, broader, and better functioning financial markets can stimulate higher economic growth (Levine, Loayza and Beck 2000; Beck, Levine, and Loayza 1999; King and Levine 1993a, 1993b). Although evidence on Africa is still limited, the results from existing empirical work supports the view that financial development has a positive effect on economic growth in African countries (Ndikumana 2000; Allen and Ndikumana 2000; Gelbard and Leite 1999; Odedokun 1996; Spears 1992). The discussion of strategies for enhancing African economic development must therefore take into account the role of the financial sector in economic development.

This chapter reviews the theory and evidence on the links between financial development and economic activity in the context of African countries. The text is organized as follows. The next section gives a brief summary of the various functions of the financial system and the mechanisms of transmission through which financial intermediation can enhance economic activity. Section III presents stylized facts on the trends and patterns of financial development in Africa since the 1970s, discusses the size and performance of African stock markets, and summarizes the findings from existing empirical studies on the effects of financial development on economic growth in African

\footnotetext{
${ }^{1}$ Levine (1997) offers a comprehensive review of the theoretical and empirical literature on the financegrowth nexus.
} 
economies. Section IV briefly discusses selected issues related to financial market development and economic development policy, namely the role of the government in the banking industry; the role of the central bank, central bank independence and regulatory efficiency; the structure of the financial system, i.e., stock market-based vs. bank-based; the capital flight problem and its effects on financial intermediation. Section V concludes.

\section{The Financial system and real economic activity: Overview}

\section{A. Functions of the financial system}

The financial system interacts with real economic activity through its various functions by which it facilitates economic exchange. ${ }^{2}$ The financial system plays an important role in mobilizing funds and transforming them into assets that can better meet the needs of investors. By facilitating portfolio diversification, financial intermediaries allow savers to maximize returns to their assets and to reduce risk. Financial intermediaries transfer resources across time and space, thus allowing investors and consumers to borrow against future income and meet current needs. This enables deficit units (those whose current expenditures exceed current income) to overcome financing constraints and the difficulties arising from mismatches between income and expenditure flows. Financial institutions play an important role in easing the tension between savers' preference for liquidity and entrepreneurs' need for long-term finance. Therefore, at any given level of saving, an efficient financial system will allow for a higher level of investment by maximizing the proportion of saving that actually finances investment (Pagano 1993). With an efficient financial system, resources will also be utilized more

\footnotetext{
2 See, among others, Merton (1995) for details on the functions of the financial system.
} 
efficiently due to the ability of financial intermediaries to identify the most productive investment opportunities.

Financial systems play an important role in creating a pricing information mechanism. By providing a mechanism for appraisal of the value of firms, financial systems allow investors to make informed decisions about the allocation of their funds. Financial intermediaries can also mitigate information asymmetries that characterize market exchange. One party to a transaction often has valuable information that the other party does not have. In such circumstances, there may be unexploited exchange opportunities. In the case of a firm, information imperfections can result in sub-optimal investment. When a manager cannot fully and credibly reveal information about a worthy investment project to outside investors and lenders, the firm may not be able to raise the outside funds necessary to undertake such a project (see Myers and Majluf 1984). In a market plagued by information imperfections, the equilibrium quantity and quality of investment will fall short of the economy's potential. Financial intermediaries can mitigate such problems by collecting information about prospective borrowers. ${ }^{3}$

The financial system can enhance efficiency in the corporate sector by monitoring management and exerting corporate control (Stiglitz 1985). Savers cannot effectively verify the quality of investment projects or the efficiency of the management. Financial intermediaries can monitor the behavior of corporate managers and foster efficient use of borrowed funds better than savers acting individually. Financial intermediaries thus fulfill the function of "delegated monitoring" by representing the interests of savers

\footnotetext{
${ }^{3}$ Note however that financial intermediaries do not fully alleviate information imperfections. Grossman and Stiglitz (1980) point out that it is indeed impossible for financial markets to be informationally efficient. The problems of imperfect information are likely to be more pronounced in developing countries
} 
(Diamond 1984). Financial markets also can improve managerial efficiency by

promoting competition through effective takeover or threat of takeover (Jensen and Meckling 1976). ${ }^{4}$

\section{B. Finance and economic growth: historical and econometric evidence}

The links between financial development and economic growth is not a new theme in the economics literature. Ninety years ago, Schumpeter (1934) ${ }^{5}$ observed that financial markets play an important role in the growth process by channeling funds to the most efficient investors and by fostering entrepreneurial innovation. Schumpeter's view was that financial development leads economic growth. Robinson (1952), however, argued that financial development passively follows economic growth by responding to the increasing demand for funds due to economic prosperity. While the debate on causality is still unsettled, existing historical and econometric evidence suggests that better functioning financial markets, i.e., markets that are able to meet the needs of savers and investors efficiently, have a positive effect on future economic growth (Levine 1997).

The economic history literature has documented cross-country and countryspecific evidence that illustrates the importance of financial systems in early industrial development. Using data from 1790 to 1850, Rouseau and Silla (1999) find quantitative evidence that supports the hypothesis that early industrial growth in the United States was finance-led. These authors conclude that by providing debt and equity finance to the

\footnotetext{
compared to advanced countries. Therefore, the ability of financial markets to allocate resources efficiently is reduced in the context of developing countries (Singh 1999; 1997).

${ }^{4}$ However, some researchers have disputed the alleged value-enhancing role of takeovers. First, information imperfections may imply a premium on the price to be paid by outside buyers (Myers and Majluf 1984). Second, the free-rider problem may deter investment in the search for information about profitable takeovers (Stiglitz 1985). Third, takeovers may result in transfers of wealth that reduce the overall social welfare (Shleifer and Summers 1988).

5 The 1934 edition of Schumpter's pioneering book is the third edition of Theorie der Wirtschaftlichen Entwicklung [The Theory of Economic Development], which was published for the first time in 1911.
} 
corporate and government sectors, the financial system was critical to the modernization process, which it predated. Using data on the United States, United Kingdom, Canada, Norway and Sweden, Rousseau and Wachtel (1998) conclude that financial intermediation was an important factor in the industrial transformation of these countries. Other studies include Corosso (1970) who documented the role of early US investment banking in mobilizing savings to raise capital; Cameron, Crisp, Patrick, and Tilly (1967) who examined European countries, Russia and Japan; and Haber (1991) who compared the cases of Brazil, Mexico and the United States. ${ }^{6}$ These studies provide evidence that supports the proposition that better functioning financial systems play an important role in economic growth.

Following the work by King and Levine (1993a, 1993b) several studies have provided econometric evidence that supports the view that financial development is a potent predictor of future economic growth. ${ }^{7}$ The results in these studies have made significant progress in establishing that to some extent, the causal relationship runs from financial development to economic growth.

The findings from studies based on aggregate data have been supported by studies that use disaggregated data on the industry and firm level. Using a large sample of industries from many countries, Rajan and Zingales (1998) find evidence indicating that financial development mitigates financing constraints for industries that rely most heavily on external finance. These authors find that such industries grow faster in countries with more developed financial systems. Demirgüç-Kunt and Maksimovic (1996) and Beck

\footnotetext{
${ }^{6}$ See Levine (1997) for more references on this topic.

${ }^{7}$ The findings from early cross-sectional analysis have been strengthened by more recent studies that use panel data econometric techniques (Levine 2000; Levine, Loayza, and Beck 2000; Beck, Levine, and Loayza 1999).
} 
and Levine (2000) provide further international firm-level evidence on the positive effects of access to a well-functioning financial system on firm growth. These studies have generalized the results from the literature on the effects of financing constraints on investment initiated by Fazzari, Hubbard and Petersen (1988) who used data from the manufacturing sector of the United States. Several studies have shown that the results on the links between financing constraints and investment by manufacturing firms hold also for developing countries. ${ }^{8}$

It is important to reiterate that while this large amount of historical and econometric evidence suggests that financial development facilitates economic growth, this does not rule out the possibility of a causal relationship in the reverse direction. It is perfectly possible that financial systems develop in response to higher economic growth or in anticipation of future prosperity. These two causal processes are not mutually exclusive and may very well be a natural feature of the links between finance and economic growth. It is in this context that we should interpret the evidence discussed in this chapter.

\section{Financial development and economic growth in Africa: An assessment}

\section{A. A note on the data}

Measuring financial development constitutes an important challenge to researchers in their efforts to assess the impact of financial intermediation on real economic activity. ${ }^{9}$ In measuring financial development, it would be ideal to obtain detailed information that enables us to assess how the financial system fulfills its roles of

\footnotetext{
${ }^{8}$ See the study by Begsten et al. (1999) on manufacturing firms in Cameroon, Ghana, Kenya, and Zimbabwe; Jaramillo, Schiantarelli, and Weiss (1996) on Ecuadorian firms; Athey and Laumas (1994) on Indian firms; and Tybout (1983) on Colombian firms.
} 
facilitating exchange, mobilizing saving, managing risk, identifying productive investment projects, and monitoring management. Such detailed information is still sparse especially in the case of developing countries.

The indicators of financial development used in empirical studies can be classified roughly in three broad categories: monetary aggregates, stock market indicators, and structural and institutional indicators.

- Monetary aggregates, also referred to as "traditional measures," are the most widely used indicators because they are the most widely published in national and international data sets. The main sources of these data are the World Bank's World Development Indicators and the IMF's International Financial Statistics. The indicators used include:

- Conventional measures of money supply such as narrow money (M1), broad money (M2), and quasi-money (M3) scaled by the country's GDP.

- Measures of the supply of credit by banks as a share of total domestic credit or as a ratio of GDP.

- Measures of the supply of credit to the private sector as a share of total domestic credit or as a ratio of GDP.

- Stock market measures include indicators of the size of the market and indicators of liquidity (see Levine and Zervos 1998). The size of the stock market is measured by the number of listed companies and the capitalization of listed companies (total volume or as ratio of GDP). Stock market liquidity is measured by the value of shares traded (volume or ratio of GDP) and the turnover ratio.

\footnotetext{
${ }^{9}$ See Levine, Loayza, and Beck (2000); Demirgüç-Kunt and Levine (1999); and Lynch (1996) for a discussion of problems related to the measurement of financial development.
} 
- Structural and institutional indicators provide information that enables us to directly or indirectly assess the efficiency and sophistication of the financial systems. These indicators include:

- Indicators of financial structure that distinguish between bank-based and stock market-based financial systems (Demirgüç-Kunt and Levine 1999; and Beck, Demirgüç-Kunt, and Levine 1999).

- Indicators of banking regulation, banking ownership structure, and banking concentration, which provide information on the degree of concentration in the banking sector, the share of state-owned vs. privately owned banks, and the level of regulatory restrictions in the business of banking (Barth, Caprio, and Levine 2000; Demirgüç-Kunt and Levine 1999). ${ }^{10}$

- Indicators of financial liberalization, which include the degree of control of the interest rate and the degree of intervention of the state in credit allocation.

In the case of African countries, recent surveys, especially those by Mehran et al (1998) and Gelbard and Leite (1999) have made a significant contribution to this area. Based on results from a survey of 38 sub-Saharan African countries in 1997, Gelbard and Leite compiled indicators on six major aspects of financial development: (1) the market structure and competitiveness of the financial system, (2) the range of financial products available on the market, (3) the degree of financial liberalization, (4) the institutional environment under which the financial system operates, (5) the degree of integration with foreign financial markets (financial openness), and (6) the degree of sophistication of monetary policy instruments. Gelbard and Leite computed indices that summarize the 
level of development of a country for each of the six aspects as well as a composite index that measures the overall level financial development in 1987 and $1997 .{ }^{11}$ Countries were then classified as undeveloped, minimally developed, somewhat developed, or largely developed. The indicators compiled in by Gelbard and Leite are highly informative not only on cross-country variations in the overall level of financial development, but also on differences in certain features of the institutional environment that are relevant for financial development. The findings from these surveys are summarized in Section D below.

\section{B. Financial development: trends and patterns}

In this section we present some stylized fats on economic performance and overall financial development using aggregate statistics based primarily on the World Bank's World Development Indicators. As can be seen from Table 1, average real income, investment, and saving have declined in the 1990s compared to the 1980 s. ${ }^{12}$ In the subSaharan African sample, average real income, investment, and saving have declined systematically in every decade since the 1970s. Table A1 in the appendix presents average real income, investment, and saving by decade for 42 African countries. According to these statistics, only twelve of the 42 countries experienced an increase in real income from the 1970s to the 1990s. For as many as 16 countries in the sample, percapita real income in the 1990s was lower than in the 1970s. These statistics illustrate what some researchers have referred to as "growth tragedy" or "development disasters"

\footnotetext{
${ }^{10}$ Measuring the degree of regulatory restrictiveness involves an assessment of the extent to which banks are allowed to engage in transactions other than the traditional operations of lending and saving mobilization (like ownership or direct involvement in the management of nonfinancial firms).

${ }^{11}$ Gelbard and Leite's survey covered only 1997 . The information for 1987 was compiled retroactively by the authors from various sources. This information was then reviewed by IMF country economists, who obtained input from country authorities and IMF resident representatives.
} 
(Easterly and Levine 1998; Chari, Kehoe, and McGrattan 1997). While the continent includes success stories like Botswana, Mauritius, and Seychelles, whose income levels are high and rising, it also includes a number of disappointing cases. Even countries with vast resources like the Democratic Republic of Congo (former Zaïre) and Nigeria have been unable to meet expectations due to many factors, including poor macroeconomic management and political corruption.

Since the 1980s, aggregate indicators of financial development have either stagnated or declined on average in sub-Saharan Africa (Table 2 and Figure 1). For subSaharan Africa, excluding South Africa, the average size of the financial system (as measured by total liquid liabilities of financial intermediaries) and credit supply were lower in the 1990s compared to the 1980s. If South Africa or North African countries (Egypt, Morocco and Tunisia) are included, the statistics show an increase in the volume of credit supply from the 1970s to the 1990s. The data also highlight the predominant size of the South African financial system. The average bank credit to GDP ratio for the sub-Saharan African sample in 1990-98 is $81 \%$ when South Africa is included, but only $26 \%$ when it is excluded. It is primarily through the supply of credit that financial intermediation stimulates real economic activity. Therefore the decline in credit supply in sub-Saharan Africa may be a factor for the poor economic performance of the subcontinent over the past two decades.

The aggregate indicators of financial development hide wide disparities across countries. As can be seen in Table A2, there is a large gap between countries with sizeable financial systems, with liquid liabilities of over $40 \%$ of GDP, and countries with

\footnotetext{
${ }^{12}$ Collier and Gunning (1999a, 1999b) offer surveys of the recent literature on economic performance in Africa.
} 
much smaller financial systems. The countries with relatively large financial systems include North African countries (Algeria, Egypt, Morocco, and Tunisia) and some subSaharan African countries such as Kenya and South Africa. These countries also have high ratios of credit supply to GDP, and most of them have experienced an increase in credit supply while credit supply declined in the majority of other sub-Saharan African countries over the 1970-1998 period.

The diversity in financial development across the African continent is illustrated also in a high concentration of the largest banks in just a few countries. Although detailed information is sparse on this topic, the existing evidence shows that North African countries and South Africa have larger banks than other countries. Table 3 contains information on the 150 largest banks in Africa in 1996. The banks from three countries, Egypt, Morocco, and South Africa account for about $75 \%$ of the assets held by the 150 largest banks. Adding Tunisian banks raises the share to over $80 \%$. Banks in these countries also account for the bulk of deposits and loans in this sub-sample of the African banking sector. There is a high disparity in the ratio of loans to deposits, varying from $37 \%$ in Côte d'Ivoire to $153 \%$ in South Africa. In some countries banks seem to have large idle capacity in credit supply. It would be worth investigating what causes the large variations in the loans/deposits ratios across countries and why banks in some countries choose to hoard cash rather than issuing loans.

\section{Stock market development}

African stock markets are characterized by high diversity in terms of age, size, and performance. The continent counts both long-established stock markets (Egypt, South Africa, Zimbabwe) dating from the 1880 s as well as more recent ones (Table 4). 
With a market capitalization of 170 billion dollars in 1998 (128\% of GDP), the South African stock market is a giant compared to tiny markets like Swaziland (85 million dollars, or $7 \%$ of GDP). Over all, the majority of African markets are still in their infancy, with a limited number of listed companies, low capitalization, and little diversity among market participants. This is the case even for markets that were established a long time ago. For example, the Egyptian stock market was largely dormant for over forty years following the policy shifts of the 1950s marked by the nationalization of industry and the adoption of central planning policy (Mecagni and Sourial 1999). The market developed substantially in the 1990s, with an increase in the number of listed companies, market capitalization and liquidity.

The African continent has experienced a relatively fast development of equity markets over the past two decades. In 1980, Africa counted only 8 active stock markets, but by 1999, the number had more than doubled, up to 17 (Table 4). ${ }^{13}$ Market capitalization also expanded significantly. The newer markets have grown fast in general, whereas the situation is more mixed among the more mature ones. Relative to GDP, stock market capitalization in Zimbabwe declined by 3.4\% from 1990 to 1998; it increased by $0.5 \%$ in South Africa, $4.8 \%$ in Nigeria, $16 \%$ in Kenya, and by $28 \%$ in Egypt over the same period. However, the observed stock market expansion has not been accompanied by any systematic improvement in economic performance (Table 5). Real income, domestic investment, and saving have declined or stagnated in the 1990s in the majority of countries with active stock markets, mirroring the overall poor economic performance in the continent as discussed earlier.

\footnotetext{
13 Table 4 does not include the recently established stock markets in Malawi (1997), Tanzania (1996), and Uganda (1997).
} 
African stock markets are highly illiquid, with very low trading and turnover ratios. Low liquidity of stock markets has important implications for real economic activity. High stock market liquidity reduces risk through risk sharing, which encourages saving and investment. It is stock market liquidity, more than the size of the market, that plays an important role in facilitating long-term (illiquid) investment (Levine and Zervos 1998). Therefore, low liquidity implies limited opportunities for the transformation of illiquid assets into liquid assets, which can constrain economic activity.

African stock markets are highly volatile, both in their growth rates and their rates of return. For example, after an increase by 261\% from 1996 to 1997, market capitalization in Zambia declined by 58\% from 1997 to 1998 . The rate of return in this market dropped from 103\% in 1997 to $-58 \%$ in 1998 . High stock market volatility has important adverse effects on the financial system as a whole and real economic activity (see Singh 1997; Pagano 1993). The weak economic base, high country-specific risk, and a weak external position constitute important obstacles to growth and stability of African stock markets.

Despite the various structural problems faced by African stock markets, some of them are highly profitable and often rank among the most lucrative markets in the world (Clark 1998: 1). This illustrates the generally high returns to foreign capital in African economies. The rates of return to foreign investment in Africa are often higher than those in other developing regions. For example, in 1997, the average rate of return to US foreign direct investment (FDI) was 25\% in Africa compared to $16 \%$ in Asia, $12 \%$ in Latin America, and 14\% in all developing countries (UNCTAD 1998). Two important 
stylized facts about FDI in Africa are worth emphasizing. ${ }^{14}$ First, the aggregate volume of FDI in Africa has increased substantially over the 1990s. Annual FDI inflows to Africa, excluding South Africa, increased from an average of $\$ 1.2$ billion in the 19811985 period to $\$ 2.9$ billion in 1986-1991, and $\$ 5.3$ billion in the $1992-1998$ period. $^{15}$

The second noteworthy stylized fact is the increasing diversification in the destination of FDI in Africa. While FDI has traditionally targeted resource-rich countries, especially oil exporters, other countries are attracting increasing attention from international investors. The share of oil exporters in total FDI in Africa declined from $70 \%$ in the 1980s to about $59 \%$ in the 1990s (Ndikumana 2001). Mozambique, Tanzania, Uganda, Zambia, and Zimbabwe, in particular, have experienced a substantial increase in FDI (Table 6 and Figure 2). The evidence suggests that FDI is responsive to improvement in the macroeconomic environment through economic and institutional reform. For example, Uganda, which has made significant progress in economic reform, has attracted more FDI than neighboring Kenya. Although Kenya has a more developed financial system than Uganda, it also has a more unstable macroeconomic and political environment, which tends to discourage foreign capital.

\section{Structural and institutional indicators of financial development}

From the surveys by Mehran et al (1998) and Gelbard and Leite (1999), we can draw the following stylized facts about the development of financial markets in African countries over the past two decades.

\footnotetext{
${ }^{14}$ For further details on private capital flows to Africa, see Ndikumana (2001); Bhinda, Griffith-Jones, Leape, and Martin (1999); and Kasekende, Kitabire, and Martin (1999).

${ }^{15}$ UNCTAD, World Investment Report (1998, 2000); UNCTAD (1995), Foreign Direct Investment in Africa.
} 
- Overall development: The structural and institutional indicators illustrate the crosscountry diversity in financial development pointed out earlier using aggregate measures. The structural and institutional indicators paint a much better picture (than aggregate indicators) for the overall financial development in the continent. Based on Gelbard and Leite's overall financial development index, the number of countries in their sample that were classified as somewhat or largely developed financially grew from two (Mauritius and South Africa) in 1987 to 27 in 1997 (see Table A2). ${ }^{16}$ According to Gelbard and Leite, the countries with the most developed financial system in 1997 were Ghana, Kenya, Mauritius, Namibia, South Africa, and Zambia. However, measures of credit supply have deteriorated in some countries that are classified as largely developed or somewhat developed. This is the case for Zambia (largely developed), Nigeria, Malawi, and others (see Figure 1). It is important to notice that the rankings in Gelbard and Leite (1999) are relative to other African countries; so they should not be interpreted as indicators of financial development from a worldwide perspective. Only Egypt, Morocco, and South Africa, which are classified among "emerging markets," can be considered as relatively developed from an international standard.

- Market structure: Ownership in the banking industry has evolved significantly from a predominantly state-controlled to a more privately owned system. In 1997, 13 out of the 38 countries in Gelbard and Leite's sample had almost complete private ownership of banks. Banks were predominantly state-owned in 10 countries in the sample, where the state accounted for at least 30 percent of bank loans and deposits. The banking system is still highly concentrated in the majority of sub-Saharan

\footnotetext{
${ }^{16}$ The sample in Table A2 does not match the sample in Gelbard-Leite's survey.
} 
African countries as indicated by the conventional Herfindahl index and the interest rate spread in the Gelbard-Leite (1999) study.

- The performance of the banking system has improved in some countries, but it is still low in the majority of countries. High proportions of non-performing loans illustrate the inefficiencies in the credit allocation process and in loan repayment enforcement mechanisms. The average share of non-performing loans for the 38 countries in Gelbard-Leite's sample was over 20 percent in 1997. Low loan repayment rates (high default rates) constitute an important handicap for the stability of the banking system and it has adverse effects on the real sector. In particular, high default rates discourage lending, thereby reducing the overall supply of credit, which depresses private investment.

- With the exception of South Africa, African financial systems offer a limited range of financial products. Gelbard and Leite (1999) find that bank lending is predominantly short term, government securities tend have short maturities (less than a year in 23 countries in 1997), banks in many countries still don't issue credit cards (issued in only 15 countries in 1997), and inter-bank lending is still underdeveloped (inexistent in 8 countries in the sample in 1997).

- The institutional environment is still deficient in many countries. Table 7 presents some indicators of the institutional environment from the Mehran et al (1998) study, namely the supervisory framework (banking law and central bank autonomy), prudential regulation (bank capital ratios), the safety net (availability of deposit insurance), and the legal infrastructure. The table shows that some of the basic requirements for effective banking regulation and supervision are still inexistent in 
many countries. For example, many countries have no provisions for deposit insurance and the legal infrastructure for the protection of bank performance is weak or inexistent in many countries.

The Gelbard-Leite (1999) study paints a brighter picture. According to the Gelbard-Leite indexes, in 1997 the institutional environment could be considered as reasonably supportive for financial intermediation in 23 countries, up from just 8 countries in 1987. The institutional environment index includes indicators of specific features of the legal system and the regulatory framework that facilitate financial intermediation. These features include the existence of property and creditors' rights and the ability of the judicial system to enforce such rights. Empirical studies have established a positive connection between financial development and the quality of the legal environment (La Porta, Lopez-de-Silanes, Shleifer, and Vishny 1998, 1997; Levine 1998). The two aspects of the legal system that are most critical for financial intermediation are the quality of laws and the effectiveness of enforcement of these laws. These two aspects must exist simultaneously. The quality of a legal system determines the rights of creditors pertaining especially to the respect for the security of loans and the ability to repossess the assets of defaulting borrowers. To encourage lending, these legal rights must be both clearly defined and effectively enforced. Enforcement of the rights of creditors requires a judiciary that maintains the rule of law, low corruption, and low risk of expropriation or contract repudiation.

While visible progress was achieved over the past years, there are important institutional constraints to financial intermediation that African countries need to address. For example, the Gelbard-Leite survey reports that in 1997 the loan recovery process was 
difficult in as many as 28 sub-Saharan countries, commercial legislation was inadequate in 14 countries, and there was no legislation of the use of checks in as many as 11 countries in the sample.

\section{E. Linking financial development and economic growth in Africa: existing evidence}

Examining the linkages between financial development and economic growth requires addressing two separate but related empirical questions. The first is whether the overall development of the financial system leads to higher economic growth. The second question is to identify the channels through which financial intermediation affects economic growth.

The empirical economic growth literature has addressed the first question by relating indicators of financial development to the growth rate of real per capita income in growth models including conventional determinants of economic growth (especially investment, human capital, and initial income). While there are only a handful of studies that focus explicitly on Africa, the existing evidence suggests that financial development has a positive effect on economic growth. Odedokun (1996) and Spears (1992) find that aggregate measures of financial intermediation have positive and statistically significant effects on the growth rate of real per capita GDP. Allen and Ndikumana (2000) find similar results in the case of the Southern African Development Community. Gelbard and Leite (1999) also find results that suggest a positive and statistically significant link between real per capita GDP growth and their indices of financial development. They find that both the level of initial financial development and the change in the overall financial development index between 1987 and 1997 are positively and significantly 
related to economic growth. ${ }^{17}$ Their results confirm the findings from earlier studies that concluded that the initial level of financial development is an important determinant of future economic growth (King and Levine 1993a). Gelbard and Leite (1999) also find that the changes in the indexes of financial liberalization, the institutional environment, and the array of financial products enter the growth equation positively and significantly.

To address the second empirical question, researchers seek to examine how financial development affects the factors that are believed to cause economic growth. These include capital accumulation, factor productivity growth, and saving. Crosscountry studies have made significant advances on this front, ${ }^{18}$ but evidence on African countries remains limited. However the existing evidence suggests that research in this area is promising. Ndikumana (2000) finds that financial development positively affects domestic investment. At this point, we are not aware of empirical studies that have linked financial development to factor productivity growth or saving in Africa.

\section{Selected issues in financial markets and economic development policy}

In this section we identify and briefly discuss some important topics related to financial development and the role of financial markets in economic development. The list is by no means exhaustive nor is the discussion in any way comprehensive.

\section{A. Government and banking}

In the early post-independence era, African governments sought to use financial development as a tool of speeding up economic growth. Governments became the main players in the creation of new financial intermediaries, including development banks and commercial banks as well as in the nationalization of commercial banks. Policymakers

\footnotetext{
${ }^{17}$ In Gelbard and Leite's regressions, the change in the financial development index is statistically significant only when it is entered simultaneously with the index of initial level of financial development.
} 
adopted the view that it was possible to foster economic growth by identifying growthpromoting sectors and providing subsidized credit to promote those sectors.

Governments also controlled interest rates, which, in the context of high and volatile inflation, often resulted in negative real interest rates.

By the 1980s, the financial sector was experiencing the same problems of mismanagement and inefficient allocation of resources that plagued the public sector in the majority of African countries. The financial system was characterized by pervasive default on loans, especially by state-owned enterprises, which accounted for a large share of the domestic credit supply. This weakened financial intermediaries, forcing governments to inject more resources in the system in the form of subsidies to keep ailing institutions afloat. The disappointing experience of government-sponsored financial development forced countries to revise their strategies. Even though the government's presence is still significant in many countries, there is a visible trend towards more private ownership of banks. As part of the financial sector reform programs initiated in the 1980s and accelerated in the 1990s, state-owned financial institutions have been privatized or restructured to reduce the share of the government in the ownership structure, and the creation of new private banks has accelerated due to the easing of licensing requirements. ${ }^{19}$ One undesirable effect of liberalization in some countries has been the proliferation of small undercapitalized institutions (World Bank 2000b). Moreover, the expansion of private sector participation has not resulted in a systematic

\footnotetext{
${ }^{18}$ See Levine, Loayza and Beck (2000) and Beck, Levine, and Loayza (1999).

${ }^{19}$ For example, in Nigeria, the number of commercial banks increased from 28 to 66 between 1985 and 1992. In Ghana, five new private banks were created between 1987 and 1994. Private sector control of the banking system is highest in Kenya, Nigeria, South Africa, and Zimbabwe (Aryeetey and Senbet 2000). See Nissanke and Aryeetey (1998) for further details on recent financial sector reforms in Africa.
} 
increase in competition in the banking sector. Banking systems in many countries are still characterized by a high degree of concentration.

The government can foster financial development by pursuing sound macroeconomic management, especially fiscal discipline to improve macroeconomic stability, which minimizes macroeconomic uncertainty. African countries have systematically suffered from bad fiscal policies that have exacerbated the effects of external shocks, resulting in high chronic fiscal deficits. At reasonable levels, fiscal deficits have minimal adverse effects on the financial system. But when fiscal deficits are chronically high, this increases the likelihood of monetary financing of the deficits and also forces the government to compete with private actors in the credit market. There is evidence that African countries that have made significant progress in macroeconomic and financial sector reform also have experienced improvement in economic performance and that their financial systems are improving. Uganda is often cited as an example of recent success in economic reform (see, among others, Kasekende and Hussain 200). The Ugandan government as well as the Bank of Uganda have progressively established a good record of credibility in policy decision making, which has promoted an environment that is conducive to private investment and growth.

The government also can enhance financial development by promoting a strong, independent, and effective legal system. The judiciary plays and important role in enforcing the constitutional protection of individual and property rights, and by adjudicating commercial disputes. The benefits of an efficient judiciary include the predictability of the legal environment and the protection of investors against policy reversals. The predictability of commercial law reduces the risk associated with saving 
and other forward-oriented transactions both in the real sector and in the financial system. As a result, this facilitates the maturity transformation role of financial intermediaries as well as portfolio management by savers.

Legal systems in many African countries do not adequately fulfill their role of facilitating and enforcing the rules of economic exchange. Legal procedures often are excessively long, which imposes costly delays on economic actors. ${ }^{20}$ The lack of autonomy of the judiciary from the executive branch and from political and business interest groups results in lack of impartiality in the handling of commercial disputes. There are wide variations across African countries in the quality of law and the effectiveness of the legal system in facilitating economic exchange. To date, there are no studies on Africa that have linked these cross-country variations in the legal system to differences in financial development. It would be worthwhile to investigate whether the results from the existing cross-country studies that suggest that enforcement of investor rights and financial market development vary depending on a country's legal origin (as suggested by La Porta et al. 1997, 1998 and Levine 1998) hold in the case of African countries. $^{21}$

\section{B. The role of the central bank: independence and regulatory efficiency}

The development of robust financial systems in African countries will necessitate the ability of central banks to exercise efficiently their functions to promote the stability of the financial system and the macroeconomy. To achieve this goal, central banks need

\footnotetext{
${ }^{20}$ For example, Widner's (2000) study on Botswana, Tanzania, and Uganda reports that in commercial cases, the delay in legal procedures often ranges from 3 to 8 years, and even 10 years some times.

${ }^{21}$ La Porta et al $(1997,1998)$ suggest that common-law countries have stronger legal protections for investors and more developed financial markets than French-civil-law countries. Using the legal environment as an instrument for financial development, Levine (1998) in turn finds that financial development has a positive effect on output growth, capital accumulation, and productivity growth.
} 
to be endowed with an adequate level of autonomy. ${ }^{22}$ In principle, central bank independence serves as a restraint on government policy, especially by shielding monetary policy from fiscal indiscipline through specific rules governing government borrowing from the central bank. This enables the central bank to exercise discretionary monetary policy rather than simply being a "printing press" for the government. Central bank independence also plays an important role in establishing credibility for monetary policy, which is a key ingredient for the stability of the macroeconomy. Credibility of the central bank facilitates decision making by private actors by reducing the uncertainty of the policy environment.

In most African countries the central bank has not performed well in their function as a restraint on government policy and they have performed poorly also in their role as a regulator of the banking sector. Until recently, most countries lacked the basic laws that govern the regulatory functions of the central bank, and even when the laws existed, they were poorly enforced. This is true for national banks as well as supranational banks as in the case of the CFA zone, for instance. We highlight three main reasons for these weaknesses. ${ }^{23}$

First, national authorities have regarded the central bank as their primary financier, and have therefore been reluctant to relinquish their political leverage over

\footnotetext{
${ }^{22}$ Central bank independence generally means "instrument independence", which is the ability of the central bank to choose the tools in order to pursue specific ultimate goals mandated by the legislature. To assess the degree of central bank independence, researchers combine information on both the (formal) legal institutional prescriptions and the actual practice. Such information include: the rules of appointment and dismissal of the governor; the legal mandate of the bank to pursue price stability (and how important this objective is relative to others); the rules and limitations on government borrowing from the central bank; the length of the term in office and turnover rate of central bank governors. Seminal works on indicators of central bank independence and the relationship between these indicators and outcomes of monetary policy include Grilli, Masciandro, and Tabellini (1991), Cukierman (1992), and Alesina and Summers (1993).
} 
monetary policy for the purpose of deficit financing. This illustrates the short-termism that characterizes political calculations on the part of national leaders.

The second factor is the poor institutional design of central banks starting from their creation. For example, while countries have rules on limits for government borrowing from the central bank, they rarely have statutory provisions for conditionality and sanctions in the event that those rules are violated. ${ }^{24}$ Moreover, the leadership of central banks (national and regional) is generally not independent of the executive branch of government. Governors of national central banks in sub-Saharan Africa (with few exceptions, like South Africa) usually have little or no independence from the government. This is also the case for the regional central banks in the CFA zone. For instance, the members of the boards of the two regional central banks of the CFA zone are representatives of Finance Ministries of member countries and include no representatives from commercial banks. Recently, many countries have made significant advances in this area with the establishment or strengthening of banking laws to provide more independence to the central bank and a stronger prudential regulation base (Aryeetey and Senbet 2000).

The third factor is the lack of a strong private financial sector lobby (Stasavage 2000). An active private financial sector lobby is an important factor in fostering central bank independence especially when the formal institutional foundation is weak or inexistent. The private financial sector has an advantage in central bank independence

\footnotetext{
${ }^{23}$ Other constraints include the lack of qualified central bank staff in the areas of supervision and regulation and the slow pace of adjustment of the regulatory framework to changes in the scale and scope of financial market operations (see Aryeetey and Senbet 2000).

${ }^{24}$ For example, most CFA member governments systematically exceeded their borrowing ceilings (by as much as $80 \%$ for the government of Côte d'Ivoire). Also governments were able to circumvent the limits by indirect borrowing via state-owned enterprises or by pushing commercial and development banks to supply credit to relieve fiscal pressures (Stasavage 2000).
} 
because it is a means to achieving greater price stability. Due to the inherent maturity mismatches between the assets and the liabilities of financial institutions, inflation volatility is highly costly for these institutions.

The willingness of politicians to grant central bank independence depends on whether the perceived problem (or political liability) is price instability or low growth. If it is the former, governments are likely to be more inclined to relinquish control over monetary policy, whereas if it is the latter, politicians may sacrifice monetary policy autonomy to the short-run benefits of expansionary monetary policy. In the long run, however, countries benefit from the macroeconomic stability that arises from monetary policy autonomy.

Before closing the discussion of central bank independence, two observations are warranted. First, while central bank independence has received the most attention, there are alternative arrangements that can be used to restrain monetary policy. ${ }^{25}$ Examples include the adherence to a fixed exchange rate regime and membership to a monetary union. However, just like in the case of central bank independence, these alternative arrangements are effective only if there are clear rules that prevent countries from reneging the commitment. Second, unlike what some scholars claim (for instance, Grilli, Masciandaro, and Tabellini 1991), having an independent central bank (or adhering to any other institutional arrangement of restraint) is not like having a free lunch. Central bank independence involves a trade-off between price stability and the ability of national authorities to respond to exogenous shocks. Excessively rigid monetary policy can be counterproductive, as was seen in the case of CFA zone countries from the 1980s to the 
early 1990s. Following the collapse of commodity prices in the late 1970s, these countries suffered the "twin blows" of declining terms of trade and real appreciation of the CFA due to the appreciation of the French Franc, especially vis-à-vis the dollar (see Ball 1999). In the end, while CFA zone countries enjoyed higher price stability than most other African countries, this came at the cost of a protracted recession that could have been avoided under a more flexible monetary policy and exchange rate regime.

\section{Does financial structure matter? Markets vs. banks}

In designing policies aimed at developing their financial systems to stimulate economic growth, African countries must address two related but distinct questions. First, what are the best strategies for fostering financial development? Second, which financial structure - bank-based or stock market-based, or a combination of the two - is most appropriate to their national objectives and their specific economic environment? While the first question has attracted substantial attention both in academia and in policy circles, the issue of financial structure has received relatively less consideration. Nonetheless, there are good reasons for why African countries must take this issue seriously. Some of these reasons are highlighted below.

First, historical evidence suggests that there is a connection between a country's stage of development and the structure of its financial system. In the early stages of development, banks play a predominant role in financing investment in infrastructure, which stimulates the growth process. As a country reaches higher levels of income, it is expected that stock markets play an increasing role. This argument has been supported both by historical studies on industrial growth (Cameron et al. 1967; Gerschenkron 1962)

\footnotetext{
${ }^{25}$ The conventional assumption is that central bankers are more conservative (have a stronger tolerance level for the costs associated with achieving low inflation) than the society as whole (Rogoff 1985). This
} 
and by more recent studies using broad data sets on financial structure around the world (Demirgüç-Kunt and Levine 1999). These studies find that more developed countries tend to have relatively larger and more liquid stock markets while the financial systems of less developed countries tend to be predominantly bank-based.

Second there is a close connection between financial structure and the type of investment finance supplied by the financial system. Banks tend to specialize in debt finance, while stock markets provide equity finance. Both forms of finance are needed for private sector activity and the economy will prosper better when both forms of finance are available.

Empirical research shows that bank loans constitute the primary source of outside funding for the corporate sector. For instance, U.S. banks provided about 62 percent of total outside finance for nonfinancial firms on average for the 1970-1998 period, while stock issues accounted for only two percent (Hubbard 2000: 8). ${ }^{26}$ Banks play a predominant role in supplying both short-term and long-term credit. By providing liquidity through short-term credit that can be used to finance working capital, banks allow businesses to release their own internal funds to finance fixed long-term capital. Banks and firms may also enter into explicit agreements whereby short-term loans are periodically renewed, which ultimately converts these loans into long-term finance. Such financing arrangements were prevalent during the English industrial revolution (Cameron et al 1967).

motivates the emphasis on central bank independence as a means to achieving price stability.

${ }^{26}$ See Fazzari, Hubbard, and Petersen (1988) and Mayer (1990) for further evidence on the composition of outside finance for nonfinancial firms. 
At their current level of development and given their immense needs for financing physical capital accumulation in infrastructure, African countries will benefit from fostering the development of a sound banking system. Some scholars have suggested that African countries should explicitly emphasize banking sector development over stock market development. For example, Ajit Singh (1999: 343) unequivocally concludes that for many African countries, pursuing stock market development is "a costly irrelevance which they can ill afford" (also see Singh and Weiss 1998). It is certainly difficult to reach a consensus on the right model of financial system that is most appropriate for African countries. The emphasis should be on promoting the right macroeconomic and institutional environment that facilitates financial intermediation in general. In such an environment, both banks and stock markets are likely to prosper.

\section{Financial intermediation and the capital flight problem}

According to recent studies, Africa as a region has the highest amount of private assets held abroad compared to other developing regions (Collier, Hoeffler and Pattillo 1999). Capital flight is pervasive especially in the severely indebted low-income countries, which at the same time are overburdened by high levels of indebtedness (Boyce and Ndikumana 2000). The illicit outflows of capital impose high costs on African economies and must be regarded by policy makers as an urgent matter of concern.

Some studies have investigated the causes or determinants of capital flight from Africa using both cross-country data and country-specific case studies. These studies find that capital flight is higher in countries (or episodes) with high corruption, bad governance, and high political instability. Olopoenia (2000) finds that capital flight in 
Uganda was higher during the periods of political and economic instability in the 1970s and the first half of the 1980s. Excessive monetary expansion, high inflation, and high fiscal deficits also tend to be correlated with high capital flight. The cross-country study by Hermes and Lensink (1992), the study by Nyoni (2000) on Tanzania, and the study by Olopoenia (2000) on Uganda provide some evidence that supports this prediction.

Another important factor of capital flight is market distortions, especially in the form of overvalued exchange rates and repressed interest rates. Nyoni (2000) finds that the black market premium, which is an indicator of market distortions, influences the level of capital flight. Based on data from Côte d'Ivoire, Nigeria, Sudan, Tanzania, Uganda, and Zaïre, the study by Lensink, Hermes, and Murinde (1998) shows that financial liberalization is associated with a decline in capital flight, indicating that reducing market distortions can contribute to reducing capital flight. High countryspecific risk leads to high capital flight, as a result of portfolio management by market participants. Using a portfolio choice approach, Collier, Hoeffler, and Pattillo (1999) conclude that high capital flight from Africa was due, among other things, to overvalued exchange rates, high country-specific risk, and high indebtedness.

High capital flight is an impediment to financial market development in various ways. Past and current capital flight constitutes a drain on national resources and depresses private saving and investment. Capital flight contributes to increasing macroeconomic uncertainty, which discourages saving and lending. This is because market participants interpret high capital flight as a signal of loss of control over economic policy by the national authorities. Through herd effects, capital flight can lead to more capital flight as agents seek to minimize expected portfolio losses in the event 
that economic (and political) conditions deteriorate further. This discourages saving in the domestic financial system, which consequently retards financial development.

\section{Conclusion}

Empirical research on the links between financial development and economic growth in Africa is still limited. However the existing evidence suggests that financial market development is positively related to the growth rate of real income. Research in this area is constrained by the lack of detailed information that can allow us to assess the extent to which financial systems fulfill their roles of facilitating exchange, identifying productive investment projects, mobilizing saving, managing risk, and monitoring management. Such information is necessary not only for research but also for formulating appropriate strategies for financial development and economic growth.

The evidence discussed in this chapter indicates that financial systems are still relatively underdeveloped in the majority of African countries. Aggregate (traditional) measures of financial intermediation show that credit supply has either stagnated or declined in most of sub-Saharan African countries in the past two decades. However, recent structural and institutional indicators of financial market development paint a relatively more optimistic picture. These indicators show that a number of countries have made significant progress in promoting an environment that is conducive to financial intermediation. This is typically the case for countries that have consistently pursued macroeconomic reforms, especially through fiscal discipline, which has promoted a stable business environment. Much progress is still needed, however, especially to strengthen the institutional framework for banking regulation, promote monetary policy autonomy, establish government and central bank credibility, develop banking 
supervision capacity (through investment in technology and human capital), which will create an environment that is conducive to investment and saving. Progress in those areas will not only promote financial market development but will also foster economic growth. 


\section{References}

Alesina, Alberto and Lawrence Summers (1993) "Central bank independence and macroeconomic performance: Some comparative evidence," Journal of Money, Credit, and Banking, 25 (2), 151-162.

Allen, Donald and Léonce Ndikumana (2000) "Financial intermediation and economic growth in Southern Africa," Journal of African Economies, 9(2), 132-160.

Aryeetey, Ernest, and Lemma Senbet (2000) "Essential financial market reforms in Africa," mimeo, University of Ghana and University of Maryland.

Athey, Michael, Perm Laumas (1994) "Internal funds and corporate investment in India," Journal of Development Economics, 45, 287-303.

Ball, R. (1999) "The institutional foundation of monetary commitment: A comparative analysis," World Development, 27(10), 1821-1842.

Beck, Thorsten and Ross Levine (2000) "New firm formation and industry growth: Does having a market-based or bank-based system matter?" University of Minnesota, Carlson School of Management, Working Paper 0004.

Beck, Thorsten, Ross Levine, and Norman Loayza (1999) "Finance and the sources of growth," University of Minnesota, Carlson School of Management, Working Paper 9907.

Bhinda, Nils, Stephany Griffith-Jones, Jonathan Leape, and Matthew Martin (1999) Private Capital Flows to Africa. Perceptions and Reality. The Hague: FONDAD.

Bigsten, Arne, Paul Collier, Stefan Dercon, Bernard Gauthier, Jan Willem Gunning, Anders Isaksson, Abena Oduro, Remco Oostendorp, Cathy Pattilo, Mans Soderbom, Michael Sylvain, Francis Teal, and Albert Zeufack (1999) "Investment in Africa's manufacturing sector: A four country panel data analysis, " Oxford Bulletin of Economics and Statistics, 61(4), 489-512.

Boyce, James K. and Léonce Ndikumana (2000) "Is Africa a net creditor? New estimates of capital flight from severely indebted sub-Saharan African countries, 1970-1996," University of Massachusetts, Department of Economics and Political Economy Research Institute, Working Paper 2000-1.

Cameron, Rondo, Olga Crisp, Hugh Patrick, and Richard Tilly (1967) Banking in the Early Stages of Industrialization. A Study in Comparative Economic History. New York: Oxford University Press.

Chari, V.V., Patrick J. Kehoe, and Ellen R. McGrattan (1997) "The poverty of nations: A quantitative investigation," Federal Reserve Bank of Minneapolis, Research Department, Staff Report 204.

Clark, Robert (1998) Africa's Emerging Securities Markets: Developments in Financial Infrastructure. Westport: Quorum Books.

Collier, Paul and Jan Willem Gunning (1999a) "Explaining African economic performance," Journal of Economic Literature, 37(1), 64-111.

Collier, Paul and Jan Willem Gunning (1999b) "Why has Africa grown slowly?" Journal of Economic Perspectives, 13(3), 3-22.

Collier, Paul, Anke Hoeffler, and Catherine Pattillo (1999) "Flight capital as a portfolio choice," World Bank, unpublished manuscript. 
Corosso, Vincent (1970) Investment Banking in America. Cambridge: Harvard University Press.

Cukierman, Alex (1992) Central Bank Strategy, Credibility, and Independence: Theory and Evidence. Cambridge: The MIT Press.

Demirgüç-Kunt, Asli and Ross Levine (1999) "Bank-based and market-based financial systems: Cross-country comparisons," The World Bank, Policy Research Working Paper 2143.

Demirgüç-Kunt, Asli and Vojislav Maksimovic (1996) "Stock Market Development and Financing Choices of Firms," World Bank Economic Review, 10(2), 341-369.

Diamond, Douglas (1984) "Financial intermediation and delegated monitoring," Review of Economic Studies, 51(3), 393-414.

Easterly, William and Ross Levine (1997) "Africa's growth tragedy. Policies and ethnic divisions," Quarterly Journal of Economics, 112(2), 103-1250.

Fazzari, Steven, Glenn Hubbard, and Bruce Petersen (1988) "Financing constraints and corporate investment," Brookings Papers on Economic Activity 1, 141-195.

Gelbard, Enrique and Sérgio Pereira Leite (1999) "Measuring financial development in sub-Saharan Africa," IMF working paper 99/105.

Global Financial Data (2000) "Capitalization, trading volumes, and number of listed companies in 1998," Global Financial Data, Los Angeles; available on the web: www.globalfindata.com.

Grilli, Vittorio, Donato Masciandaro, and Guido Tabellini (1991) "Political and monetary institutions and public financial policies in the industrial countries," Economic Policy 13, 341-392.

Grossman, Sanford and Joseph Stiglitz (1980), "On the impossibility of informationally efficient markets," American Economic Review, 70(3), 393-408.

Haber, Stephen (1991) "Industrial concentration and the capital markets: A comparative study of Brazil, Mexico, and the United States, 1830-1930," Journal of Economic History, 51(3), 559-580.

Hermes, Niels and Robert Lensink (1992) "The magnitude and determinants of capital flight: The case for six sub-Saharan African countries," De Economist 140 (4), $515-530$.

Hubbard, Glenn (2000) Money, the Financial System, and the Economy. Reading, MA: Addison-Wesley.

International Monetary Fund. International Financial Statistics (various issues).

Jaramillo, Fidel, Fabio Schiantarelli, and Andrew Weiss (1996) Capital market imperfections before and after financial liberalization: An Euler equation approach to panel data for Ecuadorian firms," Journal of Development Economics, 51, 367-386.

Jensen, Michael and W.H. Meckling (1976) "Theory of the firm: Managerial behavior, agency costs, and ownership structure," Journal of Financial Economics, 3, 305360.

Jeune Afrique Economie, "Le Classement des banques Africaines", Numéro Hors-Série, Novembre 1998.

Kasekende, Louis and Iftikhar Hussain (2000) "The central bank as a restraint: the experience of Uganda," in Collier, Paul and Catherine Pattillo (Eds.) Investment and Risk in Africa, New York: St. Martin Press, 169-181. 
King, Robert G. and Ross Levine (1993a). "Finance, entrepreneurship, and growth. Theory and Evidence," Journal of Monetary Economics, 32, 513-542.

King, Robert G. and Ross Levine (1993b). "Finance and growth: Schumpeter might be right," Quarterly Journal of Economics, 108(3), 717-737

La Porta, Rafael, Florencio Lopez-De-Silanes, Andrei Shleifer, and Robert Vishny (1997) "Legal determinants of external finance," Journal of Finance, 52(3), 1131-1150.

La Porta, Rafael, Florencio Lopez-De-Silanes, Andrei Shleifer, and Robert Vishny (1998) "Law and finance," Journal of Political Economy, 106(6), 1113-1155.

Lensink, Robert, Niels Hermes, and Victor Murinde (1998) "The effect of financial liberalization on capital flight in African economies," World Development 26(7), 1349-1368.

Levine, Ross (1997) "Financial development and economic growth: Views and agenda," Journal of Economic Literature, 35, 688-726.

Levine, Ross (1998) "The legal environment, banks, and long-run economic growth," Journal of Money, Credit, and Banking, 30(3), 596-613.

Levine, Ross (2000) "Bank-based or market-based financial systems: Which is better?" University of Minnesota, Carlson School of Management, Working Paper 0005.

Levine, Ross and Sara Zervos (1998) "Capital control liberalization and stock market development," World Development, 26(7), 1169-1183.

Levine, Ross, Norman Loayza, and Thorsten Beck (2000) "Financial intermediation and growth: Causality and Causes," Journal of Monetary Economics, 46(1), 31-77.

Lynch, David (1996) "Measuring financial sector development: A study of selected Asia-Pacific countries," Developing Economies, 32(1), 3-33.

Mayer, Colin (1990) "Financial systems, corporate finance, and economic development," In Glenn Hubbard (Ed.) Asymmetric Information, Corporate Finance and Investment . University of Chicago Press, Chicago, 307-332.

MBendi Information for Africa (2000) "African Stock Exchange 1998," Mbendi Information Services, Claremont, South Africa; available on the web: www.mbendi.co.za.

Mecagni, Mauro and Maged Sourial (1999) "The Egyptian stock market: Efficiency tests and volatility effects," IMF working paper 99/48.

Mehran, Hassanali, Piero Ugolini, Jean Philippe Briffaux, George Iden, Tonny Lybek, Stephen Swaray, and Peter Hayward (1998) "Financial sector development in sub-Saharan African Countries," IMF Occasional Paper 169.

Merton, Robert (1995) "A functional perspective of financial intermediation," Financial Management 24, 23-41.

Myers, Stewart and Nicholas Majluf (1984) "Corporate financing and investment decisions when firms have information that investors do not have," Journal of Financial Economics, 13, 187-221.

Ndikumana, Léonce (2001) "A study of capital account regimes in Africa," paper prepared for the UNCTAD workshop on "Management of capital flows: comparative experiences and implications for Africa" held in Cairo on March 2021, 2001.

Ndikumana, Léonce (2000) "Financial determinants of domestic investment in SubSaharan Africa: Evidence from panel data," World Development, Vol. 28(2): $381-400$. 
Ndikumana, Léonce and James K. Boyce (1998) "Congo's odious debt: External borrowing and capital flight in Zaire," Development and Change, 29 (2), 195-217.

Nissanke, Machiko and Ernest Aryeetey (1998) Financial Integration and Development in Sub-Saharan Africa, London: Routledge.

Nyoni, Timothy (2000) "Capital flight from Tanzania," in Ajayi, Ibi and Mohsin Khan (Eds.) External Debt and Capital Flight in Sub-Saharan Africa. Washington, DC: The IMF Institute, 265-299.

Odedokun, M.O. (1996) "Alternative econometric approaches for analyzing the role of the financial sector in economic growth: Time-series evidence from LDCs," Journal of Development Economics, 50, 119-146.

Olopoenia, Razaq (2000) "Capital flight from Uganda, 1971-94," in Ajayi, Ibi and Mohsin Khan (Eds.) External Debt and Capital Flight in Sub-Saharan Africa. Washington, D.C.: The IMF Institute, 238-264.

Pagano, Marco (1993) "Financial markets and growth," European Economic Review 37, 613-622.

Rajan, Raghuram and Luigi Zingales (1998) "Financial dependence and growth," American Economic Review, 88(3), 559-586.

Robinson, Joan (1952) The Role of Interest and Other Essays. London: Macmillan.

Rogoff, Kenneth (1985) "The optimal degree of commitment to an intermediate monetary target," Quarterly Journal of Economics, 100(4), 1169-1189.

Rousseau, Peter and Paul Wachtel (1998) "Financial intermediation and economic performance: Historical evidence from five industrialized countries," Journal of Money, Credit and Banking 30(4), 657-678.

Schumpeter, Joseph A. (1934) The Theory of Economic Development, Cambridge Harvard University Press.

Shleifer, Andrei and Lawrence Summers (1988) "Breach of trust in hostile takeovers," In Alan Auerbach (Ed.) Corporate Takeovers: Causes and Consequences. Chicago: University of Chicago Press, 33-56.

Singh, Ajit (1999) "Should Africa promote stock market capitalism?" Journal of International Development, 11, 343-365.

Singh, Ajit (1997) "Financial liberalization, stock markets and economic development," The Economic Journal, 107, 771-782.

Singh, Ajit and Bruce Weisse (1998) "Emerging stock markets, portfolio capital flows and long-term economic growth: Micro and macroeconomic perspectives," World Development, 26(4), 607-622.

Spears, Annie (1992) "The role of financial intermediation in economic growth in SubSaharan Africa," Canadian Journal of Development Studies, 13(3), 361-380.

Stasavage, David (2000) "The franc zone as a restraint," in Collier, Paul and Catherine Pattillo (Eds.) Investment and Risk in Africa, New York: St. Martin Press, 275304.

Stiglitz, Joseph (1985) "Credit markets and the control of capital," Journal of Money, Credit and Banking 17(2), 133-152.

Stiglitz, Joseph and Andrew Weiss (1981) "Credit rationing in markets with imperfect information," American Economic Review, 71(3), 393-410.

Tybout, James (1983) "Credit rationing and investment behavior in a developing country," Review of Economics and Statistics, 65(4), 598-607. 
UNCTAD (1995) Foreign Direct Investment in Africa. New York: United Nations Press. UNCTAD World Investment Report (various issues, 1992 to 2000). New York: United Nations Publications.

Widner, Jennifer (2000) "The courts as a restraint: the experience of Tanzania, Uganda, and Botswana," in Collier, Paul and Catherine Pattillo (Eds.) Investment and Risk in Africa, New York: St. Martin Press, 219-242.

World Bank (2000a) World Development Indicators 2000 (CDROM edition).

World Bank (2000b) Can Africa Claim the 21 ${ }^{\text {st }}$ Century? Washington DC: The World Bank. 
Table 1: Some indicators of economic performance for African countries, 1970-1998

\begin{tabular}{|c|c|c|c|c|c|c|c|c|c|}
\hline \multirow[t]{2}{*}{ Period } & \multicolumn{3}{|c|}{$\begin{array}{l}\text { Africa } \\
\text { (37 countries) }\end{array}$} & \multicolumn{3}{|c|}{$\begin{array}{l}\text { Sub-Saharan Africa } \\
\text { (33 countries) }\end{array}$} & \multicolumn{3}{|c|}{$\begin{array}{l}\text { SSA without South Africa } \\
\text { (32 countries) }\end{array}$} \\
\hline & $\begin{array}{l}\text { Real GNP } \\
\text { per capita } \\
\text { in } 1998 \\
(1995 \\
\text { US\$) }^{a}\end{array}$ & $\begin{array}{l}\text { Gross } \\
\text { domestic } \\
\text { investment } \\
(\% \text { GDP })\end{array}$ & $\begin{array}{l}\text { Gross } \\
\text { domestic } \\
\text { saving } \\
(\% \text { GDP) }\end{array}$ & $\begin{array}{l}\text { Real GNP } \\
\text { per capita } \\
(1995 \text { US \$) }\end{array}$ & $\begin{array}{l}\text { Gross } \\
\text { domestic } \\
\text { investment } \\
(\% \text { GDP) }\end{array}$ & $\begin{array}{l}\text { Gross } \\
\text { domestic } \\
\text { saving } \\
(\% \text { GDP) }\end{array}$ & $\begin{array}{l}\text { Real GNP } \\
\text { per capita } \\
(1995 \text { US \$) }\end{array}$ & $\begin{array}{l}\text { Gross } \\
\text { domestic } \\
\text { investment } \\
\text { (\% GDP) }\end{array}$ & $\begin{array}{l}\text { Gross } \\
\text { domestic } \\
\text { saving } \\
\text { (\% GDP) }\end{array}$ \\
\hline $1970-79$ & 793 & 23.6 & 21.3 & 769 & 21.1 & 20.9 & 379 & 21.4 & 18.7 \\
\hline $1980-89$ & 805 & 21.8 & 20.6 & 711 & 18.3 & 19.8 & 347 & 17.6 & 15.1 \\
\hline $1990-98$ & 769 & 18.8 & 17.7 & 638 & 16.2 & 16.9 & 327 & 17.9 & 16.3 \\
\hline $\begin{array}{l}\text { Average } \\
\text { annual \% } \\
\text { change: }\end{array}$ & & & & & & & & & \\
\hline $70 \mathrm{~s}$ to $80 \mathrm{~s}$ & 0.2 & -0.8 & -0.3 & -0.8 & -1.4 & -0.5 & -0.8 & -1.9 & -2.1 \\
\hline 80 s to $90 \mathrm{~s}$ & -0.5 & -1.5 & -1.5 & -1.1 & -1.2 & -1.6 & -0.6 & 0.2 & 0.8 \\
\hline
\end{tabular}

Source: Author's computations from World Development Indicators 2000.

The sample includes the countries in Tables A1 and A2, excluding Mozambique (has short time series). Lesotho has systematically negative (and large) saving rates; it is excluded in the computation of the sample average saving rate.

${ }^{a}$ The weighted average real GNP per capita in 1998 is $\$ 771$ for the sample of 37 countries but only $\$ 503$ when we exclude countries with GNP per capita over $\$ 2000$ (Botswana, Gabon, Mauritius, Seychelles, South Africa, and Tunisia). 
Table 2: Financial development indicators for African countries, 1970-1998 (\% of GDP)

\begin{tabular}{|c|c|c|c|c|c|c|c|c|c|}
\hline \multirow[t]{2}{*}{ Period } & \multicolumn{3}{|l|}{$\begin{array}{l}\text { Africa } \\
\text { (37 countries) }\end{array}$} & \multicolumn{3}{|c|}{$\begin{array}{l}\text { Sub-Saharan Africa } \\
\text { (33 countries) }\end{array}$} & \multicolumn{3}{|c|}{$\begin{array}{l}\text { SSA without South Africa } \\
\text { (32 countries) }\end{array}$} \\
\hline & $\begin{array}{l}\text { Liquid } \\
\text { liabilities }\end{array}$ & $\begin{array}{l}\text { Private } \\
\text { credit }\end{array}$ & $\begin{array}{l}\text { Bank } \\
\text { credit }\end{array}$ & $\begin{array}{l}\text { Liquid } \\
\text { liabilities }\end{array}$ & $\begin{array}{l}\text { Private } \\
\text { credit }\end{array}$ & $\begin{array}{l}\text { Bank } \\
\text { credit }\end{array}$ & $\begin{array}{l}\text { Liquid } \\
\text { liabilities }\end{array}$ & $\begin{array}{l}\text { Private } \\
\text { credit }\end{array}$ & $\begin{array}{l}\text { Bank } \\
\text { credit }\end{array}$ \\
\hline $1970-79$ & 43.7 & 39.0 & 57.6 & 42.6 & 42.9 & 59.1 & 19.5 & 14.3 & 20.5 \\
\hline $1980-89$ & 49.7 & 44.9 & 69.8 & 40.9 & 46.6 & 64.3 & 24.2 & 18.3 & 32.1 \\
\hline $1990-98$ & 47.3 & 52.8 & 76.5 & 38.1 & 64.5 & 80.7 & 22.5 & 14.6 & 26.4 \\
\hline $\begin{array}{l}\text { Average a } \\
\% \text { change: }\end{array}$ & & & & & & & & & \\
\hline $70 \mathrm{~s}$ to $80 \mathrm{~s}$ & 1.3 & 1.4 & 1.9 & -0.4 & 0.8 & 0.8 & 2.2 & 2.5 & 4.6 \\
\hline $80 \mathrm{~s}$ to $90 \mathrm{~s}$ & -0.5 & 1.6 & 0.9 & -0.7 & 3.3 & 2.3 & -0.7 & -2.2 & -1.9 \\
\hline
\end{tabular}

Source: Author's computations from World Development Indicators 2000.

The sample includes the countries in Tables A1 and A2, excluding Mozambique (has short time series). For Lesotho and Botswana, credit by bank series are from the IMF's International Financial Statistics (December 1999 CDROM edition). The series in World Development Indicators have negative bank credit to GDP ratios. 
Table 3: The 150 largest banks in Africa: deposits, credit, and revenue, 1996

\begin{tabular}{|c|c|c|c|c|c|c|c|c|c|}
\hline \multirow[t]{3}{*}{ Country } & \multicolumn{3}{|c|}{ Among the 150 largest banks } & \multicolumn{6}{|c|}{ Among the 50 largest banks } \\
\hline & \multicolumn{3}{|c|}{ Total assets } & \multicolumn{2}{|c|}{$\begin{array}{c}\text { Share in total } \\
\text { deposits }\end{array}$} & \multicolumn{2}{|c|}{$\begin{array}{l}\text { Share in total credit } \\
\text { supply }\end{array}$} & $\begin{array}{l}\text { Loans/Deposits } \\
(\%)\end{array}$ & Revenue/product(\%) \\
\hline & $\begin{array}{l}\text { Million } \\
\text { FF }\end{array}$ & $\%$ of total & $\begin{array}{l}\text { \# of } \\
\text { banks }^{\mathrm{a}}\end{array}$ & $\%$ of total & $\begin{array}{l}\text { \# of } \\
\text { banks }\end{array}$ & $\begin{array}{l}\% \text { of } \\
\text { total }\end{array}$ & \begin{tabular}{|l} 
\# of \\
banks
\end{tabular} & & \\
\hline South Africa & 28822 & 33.9 & 10 & 39.8 & 6 & 43.9 & 7 & 91.53 & 24.4 \\
\hline Egypt & 22363 & 26.3 & 21 & 34.6 & 14 & 27.4 & 15 & 77.49 & 45.4 \\
\hline Morocco & 12350 & 14.5 & 8 & 12.5 & 7 & 11.7 & 7 & 116.31 & 31.4 \\
\hline Tunisia & 5291 & 6.2 & 7 & 3.9 & 6 & 4.3 & 6 & 92.65 & 23.4 \\
\hline Algeria & 3679 & 4.3 & 3 & 1.9 & 1 & 7.0 & 2 & 152.95 & 3.8 \\
\hline Nigeria & 2014 & 2.4 & 16 & 1.5 & 3 & 0.9 & 3 & 49.97 & 55.9 \\
\hline Mauritius & 1355 & 1.6 & 3 & 0.6 & 1 & 0.4 & 1 & 51.09 & 49.6 \\
\hline Gabon & 919 & 1.1 & 3 & - & - & 0.2 & 1 & - & 28.8 \\
\hline Ethiopia & 863 & 1.0 & 2 & 1.4 & 1 & 1.4 & 1 & 83.89 & 66.2 \\
\hline Cameroon & 825 & 0.9 & 3 & 0.4 & 2 & - & - & - & - \\
\hline Côte d'Ivoire & 727 & 0.8 & 4 & 0.9 & 2 & 1.0 & 2 & 37.31 & 36.3 \\
\hline Namibia & 715 & 0.8 & 3 & 0.7 & 2 & 0.8 & 2 & 94.77 & 31.1 \\
\hline Kenya & 704 & 0.8 & 6 & 0.3 & 1 & 0.3 & 1 & 76.47 & 78.3 \\
\hline Senegal & 396 & 0.5 & 5 & 0.2 & 1 & - & - & - & \\
\hline Sudan & 387 & 0.4 & 2 & 1.0 & 2 & 0.6 & 2 & 56.04 & 127.6 \\
\hline Botswana & 354 & 0.4 & 2 & 0.2 & 1 & - & - & - & 35.5 \\
\hline Malawi & 287 & 0.3 & 3 & - & - & - & - & - & 58.6 \\
\hline Madagascar & 203 & 0.2 & 2 & - & - & - & - & - & 36.5 \\
\hline Mozambique & 108 & 0.1 & 1 & - & - & - & - & - & 50.5 \\
\hline
\end{tabular}

Source: Jeune Afrique Economie, "Le Classement des banques Africaines”, Hors-Série, Novembre 1998

${ }^{\mathrm{a}}$ The total does not add up to 150 . Only countries that are represented in 50 largest banks are included in this table. 
Table 4: Stock markets in sub-Saharan Africa: some indicators, 1990-1998 ${ }^{a}$

\begin{tabular}{|c|c|c|c|c|c|c|c|c|c|c|}
\hline \multirow[t]{3}{*}{ Country } & \multirow{3}{*}{$\begin{array}{l}\text { Year } \\
\text { established }\end{array}$} & \multirow{2}{*}{$\begin{array}{l}\text { Listed } \\
\text { companies } \\
1998\end{array}$} & \multicolumn{4}{|c|}{ Market capitalization } & \multirow{2}{*}{\multicolumn{2}{|c|}{ Capital return $(\%)$}} & \multirow{2}{*}{\multicolumn{2}{|c|}{$\begin{array}{l}\text { Trading } 1998 \\
\text { (1997 for Swaziland } \\
\text { and Zambia) }\end{array}$}} \\
\hline & & & \multicolumn{2}{|c|}{ Volume } & \multicolumn{2}{|c|}{ As $\%$ of GDP } & & & & \\
\hline & & & $\begin{array}{l}\text { Million } \\
\text { US \$ } \\
1998\end{array}$ & $\begin{array}{l}\text { Annual } \\
\% \text { growth } \\
1990-98\end{array}$ & $\begin{array}{l}\% \text { of } \\
\text { GDP } \\
1998\end{array}$ & $\begin{array}{l}\text { Annual } \\
\% \text { growth } \\
1990-98\end{array}$ & 1997 & 1998 & $\begin{array}{l}\text { Value (\% } \\
\text { GDP) }\end{array}$ & $\begin{array}{l}\text { Turnover } \\
\text { ratio }(\%)\end{array}$ \\
\hline Botswana & 1989 & 14 & 724 & 15.7 & 14.8 & 12.1 & 92.2 & 14.3 & 1.4 & 1.1 \\
\hline $\begin{array}{l}\text { Côte } \\
\text { d'Ivoire }^{b}\end{array}$ & 1976 & 35 & 1818 & 16.1 & 16.5 & 15.8 & 3.6 & 22.9 & 0.3 & 4.5 \\
\hline Egypt & 1888 & 861 & 24381 & 38.8 & 29.5 & 28.0 & 15.8 & -26.6 & 6.1 & 22.3 \\
\hline Ghana & 1989 & 21 & 1384 & 51.4 & 18.5 & 48.6 & 9.5 & 63.1 & 0.8 & 6.5 \\
\hline Kenya & 1954 & 58 & 2024 & 20.6 & 17.5 & 16.1 & -12.2 & -3.5 & 0.7 & 0.3 \\
\hline Mauritius & 1988 & 40 & 1849 & 27.3 & 44.0 & 20.2 & -0.2 & 5.8 & 2.4 & 2.9 \\
\hline Morocco & 1929 & 53 & 15676 & 41.7 & 44.1 & 36.1 & 35.3 & 26.4 & 3.9 & 10.1 \\
\hline Namibia & 1992 & 15 & 429 & 65.3 & 13.8 & 63.9 & 4.7 & -46.6 & 0.4 & 2.3 \\
\hline Nigeria & 1960 & 186 & 2887 & 9.7 & 7.0 & 4.8 & -8.6 & -20.8 & 0.4 & 5.2 \\
\hline South & 1887 & 668 & 170252 & 2.7 & 127.6 & 0.5 & -10.4 & -27.6 & 43.8 & 30.4 \\
\hline Africa & & & & & & & & & & \\
\hline Swaziland & 1990 & 5 & 85 & 22.3 & 7.0 & 17.0 & na & na & 28.8 & 126 \\
\hline Tunisia & 1969 & 38 & 2268 & 19.8 & 11.4 & 12.8 & -29.7 & 5.9 & 0.9 & 0.9 \\
\hline Zambia & 1994 & 8 & 293 & 148.9 & 8.7 & 151.8 & 103.3 & -58 & 0.2 & 2.0 \\
\hline Zimbabwe & 1896 & 67 & 1310 & -7.3 & 20.7 & -3.4 & -53.1 & -54.8 & 2.6 & 9.2 \\
\hline
\end{tabular}

Sources: World Bank, World Development Indicators 2000; Global Financial Data (www.globalfindata.com); MBendi Information for Africa (1998), “African Capital Market 1998" (www.mbendi.co.za).

${ }^{\text {a }}$ The data for 1990 are not available for some countries. The relevant years are: 1991 for Botswana and Ghana, 1992 for Namibia, and 1995 for Zambia.

Countries with recently established stock markets are not included in this table. These are Malawi (established in 1997), Tanzania (established in 1996), and Uganda (established in 1997).

$\mathrm{b}$ The Abidjan Stock Exchange was officially closed in December 1997, ahead of the opening of the regional stock exchange (Bourse Régionale des Valeurs Mobilières, BRVM). 
Table 5: Some economic performance indicators for African countries with stock markets, 1990-1998

\begin{tabular}{|c|c|c|c|c|c|c|c|c|}
\hline \multirow[t]{2}{*}{ Country } & \multicolumn{2}{|c|}{ Real per capita GDP } & \multicolumn{2}{|c|}{ Gross domestic saving } & \multicolumn{2}{|c|}{ Gross domestic investment } & \multicolumn{2}{|c|}{$\begin{array}{l}\text { FDI as \% of gross fixed } \\
\text { capital formation }\end{array}$} \\
\hline & $\begin{array}{l}\text { Value for } \\
1998 \\
\text { (in } 1995 \\
\text { US \$) }\end{array}$ & $\begin{array}{c}\text { Annual \% } \\
\text { growth 1990- } \\
1998^{\mathrm{b}}\end{array}$ & $\begin{array}{l}\% \text { of } \\
\text { GDP } \\
1998\end{array}$ & $\begin{array}{c}\text { Annual \% } \\
\text { growth 1990- } \\
1998\end{array}$ & $\begin{array}{l}\% \text { of } \\
\text { GDP } \\
1998\end{array}$ & $\begin{array}{c}\text { Annual \% } \\
\text { growth 1990- } \\
1998\end{array}$ & 1992 & 1998 \\
\hline Botswana & 3611 & 1.7 & 21.8 & -3.5 & 20.6 & -4.6 & -0.1 & 7.5 \\
\hline $\begin{array}{l}\text { Côte } \\
\text { d'Ivoire }^{\mathrm{c}}\end{array}$ & 823 & 0.6 & 24.5 & 12.5 & 18.2 & 13.6 & -29.1 & 15.7 \\
\hline Egypt & 1146 & 2.2 & 15.8 & -1.5 & 22.2 & -2.8 & 5.3 & 6.1 \\
\hline Ghana & 399 & 1.5 & 13.2 & 15.8 & 22.9 & 6.7 & 2.5 & 3.4 \\
\hline Kenya & 334 & -0.6 & 6.7 & -10.1 & 14.4 & -2.1 & 0.5 & 2.2 \\
\hline Mauritius & 4034 & 3.8 & 24.0 & -0.4 & 24.1 & -2.6 & 1.7 & 1.3 \\
\hline Morocco & 1388 & 0.4 & 14.7 & -1.5 & 22.6 & -1.9 & 6.6 & 4.1 \\
\hline Namibia & 2133 & 0.8 & 18.8 & 3.5 & 19.0 & -1.4 & 20.2 & 12.9 \\
\hline Nigeria & 256 & -0.3 & 11.8 & -6.5 & 20.0 & -2.5 & 26.3 & 12.7 \\
\hline South & 3918 & -0.2 & 16.9 & 0.2 & 15.6 & 4.7 & -0.2 & 2.5 \\
\hline Africa & & & & & & & & \\
\hline Swaziland & 1409 & -0.2 & 19.2 & 0.1 & 12.3 & 0.3 & 33.8 & 35.8 \\
\hline Tunisia & 2283 & 2.7 & 24.3 & -1.5 & 27.5 & -3.3 & 12.5 & 13.6 \\
\hline Zambia & 388 & -1.7 & 5.3 & 11.1 & 14.3 & 0.8 & 12.9 & 44.3 \\
\hline Zimbabwe & 703 & 0.0 & 15.4 & -1.2 & 17.2 & -0.8 & 1.3 & 39.8 \\
\hline
\end{tabular}

Source: Author's computations from World Development Indicators 2000. FDI data are from UNCTAD's World Investment Report (1998, 2000).

a The data for 1990 are not available for some countries. The relevant years are: 1991 for Botswana and Ghana, 1992 for Namibia, and 1995 for Zambia.

$\mathrm{b}$ The annual average changes are obtained with an OLS regression of the logarithm of the relevant variable on time (a time trend).

${ }^{c}$ The Abidjan Stock Exchange was officially closed in December 1997, ahead of the opening of the regional stock exchange (Bourse Régionale des Valeurs Mobilières, BRVM). 
Table 6: FDI inflows in selected African countries, 1986-1998 (million, constant 1995 \$)

\begin{tabular}{|c|c|c|c|c|c|c|c|c|c|c|c|c|c|c|}
\hline Country & 1986 & 1987 & 1988 & 1989 & 1990 & 1991 & 1992 & 1993 & 1994 & 1995 & 1996 & 1997 & 1998 & 1999 \\
\hline \multicolumn{15}{|c|}{ Countries with active stock markets } \\
\hline Botswana & 87 & 138 & 47 & 47 & 41 & -9 & -2 & -301 & -15 & 70 & 69 & 98 & 90 & 111 \\
\hline Côte d'Ivoire & 88 & 107 & 61 & 21 & 23 & 17 & -246 & 92 & 122 & 268 & 295 & 440 & 315 & 277 \\
\hline Egypt & 1516 & 1150 & 1388 & 1389 & 788 & 271 & 489 & 517 & 1301 & 596 & 623 & 868 & 1080 & 1491 \\
\hline Ghana & 5 & 6 & 6 & 17 & 16 & 21 & 24 & 131 & 241 & 107 & 117 & 81 & 56 & 114 \\
\hline Kenya & 41 & 52 & 0 & 69 & 61 & 20 & 6 & 2 & 4 & 32 & 13 & 39 & 42 & 42 \\
\hline Mauritius & 9 & 21 & 28 & 40 & 44 & 20 & 16 & 16 & 21 & 19 & 36 & 54 & 12 & 49 \\
\hline Morocco & 1 & 73 & 99 & 186 & 244 & 339 & 450 & 516 & 571 & 335 & 349 & 1055 & 330 & 842 \\
\hline Namibia & NA & NA & -2 & -1 & 31 & 129 & 126 & 58 & 102 & 153 & 126 & 82 & 77 & 113 \\
\hline Nigeria & 208 & 732 & 440 & 2092 & 631 & 762 & 955 & 1411 & 2030 & 1079 & 1558 & 1505 & 1054 & 1392 \\
\hline South Africa & -66 & -91 & 514 & 1517 & 1883 & 227 & -45 & -20 & 394 & 1241 & 800 & 3732 & 563 & 1368 \\
\hline Swaziland & 39 & 58 & 63 & 83 & 42 & 85 & 88 & 73 & 26 & 33 & -61 & -47 & 51 & -4 \\
\hline Tunisia & 78 & 112 & 71 & 88 & 80 & 134 & 560 & 485 & 586 & 378 & 343 & 358 & 672 & 366 \\
\hline Zambia & 35 & 91 & 108 & 182 & 218 & 36 & 48 & 55 & 41 & 97 & 114 & 202 & 199 & 162 \\
\hline Zimbabwe & 10 & -38 & -21 & -11 & -13 & 3 & 21 & 40 & 42 & 118 & 79 & 132 & 445 & 59 \\
\hline \multicolumn{15}{|c|}{ Countries without Stock markets } \\
\hline Angola & 78 & 112 & 153 & 222 & -360 & 712 & 307 & 317 & 176 & 472 & 177 & 403 & 1117 & 1803 \\
\hline Cameroon & 24 & 15 & 78 & 0 & -67 & -16 & 31 & 5 & -9 & 7 & 34 & 44 & 50 & 40 \\
\hline Congo & 27 & 52 & 10 & 3 & 8 & 5 & 4 & 156 & 5 & 3 & 8 & 9 & 4 & 5 \\
\hline Gabon & 137 & 109 & 155 & -34 & 79 & -59 & 135 & -120 & -104 & -113 & 305 & 140 & 212 & 199 \\
\hline Lesotho & 2 & 7 & 24 & 14 & 18 & 9 & 3 & 16 & 283 & 275 & 280 & 263 & 263 & 135 \\
\hline Mozambique & 0 & 0 & 6 & 3 & 10 & 25 & 27 & 34 & 36 & 45 & 71 & 63 & 214 & 382 \\
\hline Tanzania* & -10 & -1 & 5 & 7 & -3 & 3 & 13 & 21 & 52 & 150 & 146 & 155 & 172 & 182 \\
\hline Uganda* & 0 & 0 & -5 & -7 & -16 & 1 & 3 & 58 & 91 & 125 & 117 & 171 & 211 & 179 \\
\hline
\end{tabular}

Source: UNCTAD, World Investment Reports (various issues 1992 to 2000). Nominal values are deflated to real values using the US PPI index (base 1995=100) from the International Financial Statistics Yearbook (various issues).

* Stock markets recently established (1996 in Tanzania, 1997 in Uganda). 
Table 7: Indicators of banking regulation and supervision in selected sub-Saharan African countries, 1997

\begin{tabular}{|c|c|c|c|c|c|}
\hline \multirow[t]{2}{*}{ Country/group } & \multicolumn{2}{|l|}{ Supervisory framework } & \multirow{2}{*}{$\begin{array}{l}\text { Prudential } \\
\text { regulation } \\
\text { Capital ratio (\%) }\end{array}$} & \multirow{2}{*}{$\begin{array}{l}\text { Safety net } \\
\text { Deposit insurance } \\
\text { available }\end{array}$} & \multirow{2}{*}{$\begin{array}{l}\text { Legal infrastructure } \\
\text { Adequate legal } \\
\text { protection of bank } \\
\text { performance }\end{array}$} \\
\hline & Banking law (year) & $\begin{array}{l}\text { Central bank } \\
\text { autonomy }\end{array}$ & & & \\
\hline Angola & Draft completed & Limited & Negative to $>20$ & n.a. & No \\
\hline $\mathrm{BCEAO}^{\mathrm{a}}$ & 1990 & Average & n.a. & Under consideration & No \\
\hline $\mathrm{BEAC}^{\mathrm{b}}$ & 1992 & Average & n.a. & $\begin{array}{l}\text { No, agreement } \\
\text { reached for a scheme }\end{array}$ & No \\
\hline Botswana & 1995 & Full & 19.8 & No, under discussion & No, plans under way \\
\hline Ethiopia & 1994 & Limited & 4.5 & No & No \\
\hline Ghana & 1989 & Average & 14.7 & No & No \\
\hline Kenya & 1991 & Partial & 18 & Yes & No \\
\hline Lesotho & 1973 & Low & 5 & No & Yes \\
\hline Madagascar & 1996 & Full & n.a. & No & No \\
\hline Malawi & 1989 & Average & 36.2 & No & No \\
\hline Mauritius & $1966 ; 1988 ; 1995^{\mathrm{c}}$ & Full & $9-10$ & No & Yes \\
\hline Mozambique & 1992 & Average & 13 & No & n.a. \\
\hline Namibia & 1965 & Full & $>8$ & No & Yes \\
\hline Rwanda & About to be adopted & Full & 5 & No & No \\
\hline South Africa & $\begin{array}{l}\text { Banks Act 1990; } \\
\text { Mutual Banks Act } 1993\end{array}$ & Full & 9.8 & No, proposed & Yes \\
\hline Swaziland & 1975 & Full & 8 & No & No \\
\hline
\end{tabular}


Table 7 (concluded): Indicators of banking regulation and supervision in selected sub-Saharan African countries, 1997

\begin{tabular}{|l|l|l|l|l|l|}
\hline Country/group & \multicolumn{2}{|l|}{ Supervisory framework } & $\begin{array}{l}\text { Prudential } \\
\text { regulation }\end{array}$ & Safety net & Legal infrastructure \\
\hline & Banking law (year) & $\begin{array}{l}\text { Central bank } \\
\text { autonomy }\end{array}$ & Capital ratio (\%) & $\begin{array}{l}\text { Deposit insurance } \\
\text { available }\end{array}$ & $\begin{array}{l}\text { Adequate legal } \\
\text { protection of bank } \\
\text { performance }\end{array}$ \\
Tanzania & 1991 & Low & 1.55 & No \\
Uganda & $1964 ; 1993 ; 1993^{d}$ & Full & 6.15 & Yes \\
Zambia & 1994 & Average & 15 & Yes \\
Zimbabwe & 1965 & Low & 10.1 & No, proposed & No \\
No & & & No \\
\hline
\end{tabular}

Source: Mehran, Hassanali et al (1998) "Financial sector development in sub-Saharan African countries," IMF Occasional Paper 169.

${ }^{a}$ BCEAO = Benin, Burkina Faso, Côte d'Ivoire, Mali, Niger, Senegal, Togo (and Guinea-Bissau as of 1997).

${ }^{\mathrm{b}}$ BEAC $=$ Cameroon, Central African Republic, Republic of Congo, Equatorial Guinea, and Gabon.

${ }^{c}$ Mauritius: Bank of Mauritius Act in 1966, Banking Act in 1988, and Foreign Exchange Dealers Act in 1995.

${ }^{d}$ Uganda: Bills of Exchange Act in 1964; Bank of Uganda Statute in 1993; Financial Institutions Statute in 1993.

${ }^{\mathrm{e}}$ Uganda: No special legal facilities ensuring contracts performance. 
Table A1: GNP, investment, and saving for African countries (averages by decade), 1970-1998

\begin{tabular}{|c|c|c|c|c|c|c|c|c|c|}
\hline \multirow[t]{2}{*}{ Country } & \multicolumn{3}{|c|}{$\begin{array}{l}\text { Real GNP per capita } \\
\text { (at } 1995 \text { US \$) }\end{array}$} & \multicolumn{3}{|c|}{$\begin{array}{l}\text { Gross domestic investment } \\
\text { (\% of GDP) }\end{array}$} & \multicolumn{3}{|c|}{$\begin{array}{l}\text { Gross domestic saving } \\
\text { (\% of GDP) }\end{array}$} \\
\hline & \begin{tabular}{|l|}
$1970-79$ \\
\end{tabular} & 1980-89 & $1990-98$ & $1970-79$ & $1980-89$ & $1990-98$ & $1970-79$ & $1980-89$ & $1990-98$ \\
\hline Algeria & 1429 & 1699 & 1458 & 41.6 & 33.9 & 28.8 & 35.1 & 35.4 & 30.1 \\
\hline Benin & 349 & 365 & 359 & 15.5 & 15.1 & 16.2 & 2.7 & 1.1 & 7.4 \\
\hline Botswana & 929 & 2109 & 3330 & 39.7 & 28.8 & 26.7 & 28.5 & 41.5 & 35.8 \\
\hline Burkina Faso & 201 & 223 & 239 & 21.3 & 19.7 & 22.5 & 3.0 & -1.0 & 7.4 \\
\hline Burundi & 165 & 191 & 175 & 8.2 & 16.6 & 12.1 & 3.3 & 3.1 & -3.1 \\
\hline Cameroon & 529 & 853 & 616 & 21.4 & 23.8 & 16.1 & 18.3 & 24.1 & 19.0 \\
\hline Central African Republic & 455 & 395 & 329 & 15.0 & 10.9 & 11.0 & 4.2 & -1.1 & 2.7 \\
\hline Chad & 246 & 207 & 223 & 14.9 & 6.5 & 11.3 & 6.2 & -9.1 & -2.5 \\
\hline Congo, DRC & 375 & 285 & 152 & 16.3 & 11.7 & 7.0 & 12.8 & 10.9 & 8.5 \\
\hline Congo, Rep. & 611 & 919 & 719 & 29.7 & 32.5 & 33.3 & 12.0 & 31.9 & 26.8 \\
\hline Côte d'Ivoire & 1009 & 832 & 684 & 24.1 & 16.5 & 11.4 & 27.4 & 19.6 & 16.8 \\
\hline Egypt & 507 & 769 & 1016 & 23.1 & 28.6 & 19.4 & 11.6 & 15.5 & 13.5 \\
\hline Gabon & 5257 & 4453 & 3908 & 46.4 & 34.6 & 24.3 & 54.3 & 44.3 & 41.8 \\
\hline Gambia & 339 & 364 & 347 & 12.0 & 19.7 & 20.3 & 2.3 & 6.5 & 6.1 \\
\hline Ghana & 443 & 345 & 376 & 10.2 & 7.8 & 19.8 & 10.2 & 4.8 & 8.9 \\
\hline Kenya & 285 & 323 & 323 & 23.2 & 20.3 & 16.6 & 19.8 & 15.9 & 14.0 \\
\hline Lesotho & 469 & 623 & 653 & 21.9 & 46.0 & 76.8 & -57.8 & -72.9 & -27.1 \\
\hline Madagascar & 359 & 273 & 235 & 9.8 & 10.6 & 11.8 & 4.2 & 3.3 & 3.9 \\
\hline Malawi & 166 & 163 & 166 & 27.2 & 18.6 & 17.7 & 14.4 & 11.8 & 4.8 \\
\hline Mali & 270 & 260 & 251 & 15.5 & 17.2 & 22.7 & 2.2 & -0.4 & 7.4 \\
\hline Mauritania & 466 & 442 & 429 & 17.2 & 24.2 & 18.5 & 5.0 & 2.8 & 7.4 \\
\hline Mauritius & 1615 & 2146 & 3438 & 23.9 & 23.7 & 28.3 & 20.1 & 20.4 & 24.2 \\
\hline
\end{tabular}


Table A1 (continued): GNP, investment, and saving for African countries (averages by decade), 1970-1998

\begin{tabular}{|c|c|c|c|c|c|c|c|c|c|}
\hline \multirow[t]{2}{*}{ Country } & \multicolumn{3}{|c|}{$\begin{array}{l}\text { Real GNP per capita } \\
\text { (at } 1995 \text { US \$) }\end{array}$} & \multicolumn{3}{|c|}{$\begin{array}{l}\text { Gross domestic investment } \\
(\% \text { of GDP) }\end{array}$} & \multicolumn{3}{|c|}{$\begin{array}{l}\text { Gross domestic saving } \\
(\% \text { of GDP) }\end{array}$} \\
\hline & $1970-79$ & $1980-89$ & $1990-98$ & $1970-79$ & $1980-89$ & $1990-98$ & $1970-79$ & $1980-89$ & $1990-98$ \\
\hline Morocco & 954 & 1128 & 1276 & 22.6 & 24.4 & 22.1 & 15.2 & 13.5 & 13.4 \\
\hline Mozambique & NA & 133 & 143 & NA & 8.1 & 17.9 & NA & -10.3 & -8.6 \\
\hline Niger & 333 & 265 & 209 & 15.6 & 15.3 & 8.6 & 6.7 & 7.3 & 2.6 \\
\hline Nigeria & 271 & 214 & 229 & 22.9 & 16.5 & 18.6 & 22.7 & 17.5 & 23.2 \\
\hline Rwanda & 253 & 307 & 227 & 11.7 & 15.3 & 14.5 & 6.0 & 5.0 & -5.7 \\
\hline Senegal & 587 & 546 & 537 & 14.6 & 12.1 & 16.1 & 7.8 & 0.1 & 9.8 \\
\hline Seychelles & 3671 & 4691 & 6638 & 38.8 & 26.4 & 30.9 & 32.0 & 24.1 & 22.5 \\
\hline Sierra Leone & 303 & 286 & 194 & NA & 5.9 & 8.4 & NA & 3.4 & 8.3 \\
\hline South Africa & 4139 & 4200 & 3821 & 20.8 & 18.9 & 14.6 & 22.4 & 23.6 & 17.4 \\
\hline Sudan & 240 & 218 & 221 & 15.1 & 14.4 & NA & 9.6 & 5.0 & NA \\
\hline Swaziland & 875 & 1163 & 1519 & 27.4 & 26.5 & 26.2 & 30.7 & 12.9 & 21.8 \\
\hline Togo & 395 & 375 & 323 & 28.1 & 19.5 & 16.0 & 27.7 & 12.3 & 8.6 \\
\hline Tunisia & 1276 & 1630 & 1925 & 26.2 & 28.8 & 28.5 & 23.6 & 22.7 & 24.0 \\
\hline Uganda & & 230 & 284 & 9.7 & 8.5 & 15.2 & 10.0 & 2.3 & 3.6 \\
\hline Zambia & 587 & 445 & 381 & 30.2 & 16.1 & 14.1 & 33.2 & 14.0 & 8.3 \\
\hline Zimbabwe & 666 & 648 & 649 & 18.9 & 17.3 & 19.7 & 19.2 & 16.5 & 16.6 \\
\hline
\end{tabular}

Source: World Development Indicators 2000. 
Table A2: Financial development indicators for African countries (averages by decade), 1980-1998

\begin{tabular}{|c|c|c|c|c|c|c|c|c|}
\hline \multirow[t]{2}{*}{ Country } & \multicolumn{2}{|c|}{ Overall development ${ }^{a}$} & \multicolumn{2}{|c|}{$\begin{array}{l}\text { Liquid liabilities } \\
(\% \text { GDP })\end{array}$} & \multicolumn{2}{|c|}{$\begin{array}{l}\text { Credit to private sector } \\
(\% G D P)\end{array}$} & \multicolumn{2}{|c|}{$\begin{array}{l}\text { Credit by banks } \\
(\% \text { GDP })\end{array}$} \\
\hline & 1987 & 1997 & $1980-89$ & $1990-98$ & $1980-89$ & $1990-98$ & $1980-89$ & $1990-98$ \\
\hline Algeria & & & 71.9 & 47.5 & 54.1 & 13.6 & 82.0 & 54.0 \\
\hline Benin & Min. dev. & Somewhat dev. & 22.3 & 26.5 & 27.7 & 11.0 & 27.4 & 12.0 \\
\hline Botswana & Min. dev. & Somewhat dev. & 24.7 & 23.2 & 9.7 & 11.9 & 12.2 & 13.0 \\
\hline Burkina Faso & Min. dev. & Somewhat dev. & 16.8 & 22.6 & 15.5 & 11.3 & 13.4 & 10.2 \\
\hline Burundi & & & 17.4 & 19.6 & 10.5 & 16.8 & 24.4 & 23.4 \\
\hline Cameroon & Min. dev. & Somewhat dev. & 21.7 & 17.6 & 27.1 & 13.5 & 25.4 & 23.7 \\
\hline Central African Republic & Min. dev. & Min. dev. & 17.9 & 18.6 & 10.3 & 4.8 & 17.8 & 12.5 \\
\hline Chad & & & 15.7 & 12.6 & 13.2 & 4.8 & 17.0 & 11.8 \\
\hline Congo, DRC & Min. dev. & Min. dev. & 14.9 & 15.0 & 2.2 & 1.1 & 9.2 & 13.2 \\
\hline Congo, Rep. & Undev. & Somewhat dev. & 17.4 & 17.4 & 20.0 & 10.8 & 25.3 & 22.1 \\
\hline Côte d'Ivoire & Min. dev. & Somewhat dev. & 28.6 & 27.9 & 38.1 & 25.8 & 44.9 & 36.3 \\
\hline Egypt & & & 85.6 & 82.6 & 31.7 & 35.9 & 108.4 & 88.7 \\
\hline Gabon & Min. dev. & Somewhat dev. & 19.9 & 16.1 & 19.2 & 9.9 & 23.5 & 19.2 \\
\hline Gambia & Min. dev. & Somewhat dev. & 24.5 & 24.9 & 19.3 & 10.5 & 41.8 & 6.8 \\
\hline Ghana & Min. dev. & Largely dev. & 14.8 & 17.1 & 2.8 & 5.8 & 21.0 & 22.7 \\
\hline Kenya & Min. dev. & Somewhat dev. & 29.0 & 39.3 & 30.1 & 33.1 & 47.4 & 52.9 \\
\hline Lesotho & Undev. & Min. dev. & 49.8 & 37.8 & 13.2 & 19.0 & 28.8 & 23.9 \\
\hline Madagascar & Min. dev. & Somewhat dev. & 17.0 & 20.3 & 18.5 & 13.7 & 39.6 & 23.0 \\
\hline Malawi & Undev. & Min. dev. & 21.9 & 19.4 & 13.1 & 8.3 & 33.6 & 16.2 \\
\hline Mali & Min. dev. & Somewhat dev. & 20.1 & 22.3 & 17.1 & 12.5 & 27.5 & 12.4 \\
\hline Mauritania & & & 21.9 & 21.3 & 27.9 & 31.4 & 34.7 & 31.8 \\
\hline Mauritius & Somewhat dev. & Largely dev. & 49.2 & 72.9 & 25.9 & 43.9 & 55.3 & 61.6 \\
\hline
\end{tabular}


Table A2 (continued): Financial development indicators for African countries (averages by decade), 1980-1998

\begin{tabular}{|c|c|c|c|c|c|c|c|c|}
\hline \multirow[t]{2}{*}{ Country } & \multicolumn{2}{|c|}{ Overall development ${ }^{a}$} & \multicolumn{2}{|c|}{$\begin{array}{l}\text { Liquid liabilities } \\
(\% \text { GDP })\end{array}$} & \multicolumn{2}{|c|}{$\begin{array}{l}\text { Credit to private sector } \\
(\% \text { GDP })\end{array}$} & \multicolumn{2}{|c|}{$\begin{array}{l}\text { Credit by banks } \\
(\% \text { GDP })\end{array}$} \\
\hline & 1987 & 1997 & $1980-89$ & $1990-98$ & $1980-89$ & $1990-98$ & $1980-89$ & $1990-98$ \\
\hline Morocco & & & 44.6 & 63.1 & 19.0 & 32.0 & 47.9 & 58.1 \\
\hline Mozambique & Undev. & Somewhat dev. & 41.7 & 26.0 & 37.2 & 13.9 & 51.9 & 6.7 \\
\hline Niger & Min. dev. & Somewhat dev. & 16.3 & 14.9 & 16.4 & 7.8 & 18.5 & 11.9 \\
\hline Nigeria & Min. dev. & Somewhat dev. & 29.4 & 18.3 & 15.4 & 8.6 & 37.7 & 21.2 \\
\hline Rwanda & & & 14.3 & 15.9 & 7.2 & 7.3 & 9.4 & 15.5 \\
\hline Senegal & Min. dev. & Somewhat dev. & 27.1 & 23.0 & 36.1 & 21.1 & 46.9 & 27.8 \\
\hline Seychelles & & & 31.3 & 52.5 & 12.7 & 14.9 & 35.6 & 73.2 \\
\hline Sierra Leone & & & 18.5 & 12.2 & 4.4 & 3.0 & 30.9 & 42.9 \\
\hline South Africa & Largely dev. & Largely dev. & 54.2 & 51.9 & 68.8 & 108.2 & 89.8 & 128.1 \\
\hline Sudan & & & 28.3 & 16.1 & 10.8 & 3.6 & 32.0 & 13.8 \\
\hline Swaziland & Min. dev. & Somewhat dev. & 31.6 & 30.0 & 20.6 & 21.7 & 16.1 & 4.7 \\
\hline Togo & Min. dev. & Min. dev. & 39.5 & 29.5 & 24.3 & 21.7 & 26.2 & 23.8 \\
\hline Tunisia & & & 45.9 & 47.7 & 49.4 & 52.8 & 56.7 & 57.1 \\
\hline Uganda & Min. dev. & Somewhat dev. & 12.1 & 10.3 & 3.3 & 4.3 & 23.2 & 8.5 \\
\hline Zambia & Min. dev. & Largely dev. & 31.7 & 17.8 & 14.8 & 7.5 & 63.2 & 58.8 \\
\hline Zimbabwe & Min. dev. & Somewhat dev. & 24.6 & 23.5 & 20.0 & 31.0 & 42.7 & 49.4 \\
\hline
\end{tabular}

Source: World Development Indicators 2000. Gelbard and Leite (1999) "Measuring financial development in sub-Saharan Africa," IMF, working paper 99/105.

a This is Gelbard and Leite's (1999) assessment of overall development (sample includes only sub-Saharan African countries). The categories correspond to the four quartiles based on a composite index including six aspects of financial development: market structure, range of financial products, financial liberalization, institutional environment, openness, and monetary policy instruments. The categories are: undeveloped (undev.), minimally developed (min. dev.), somewhat developed (somewhat dev.), and largely developed (largely dev.). 


\section{Figure 1: Financial development in Africa, 1970-1998}
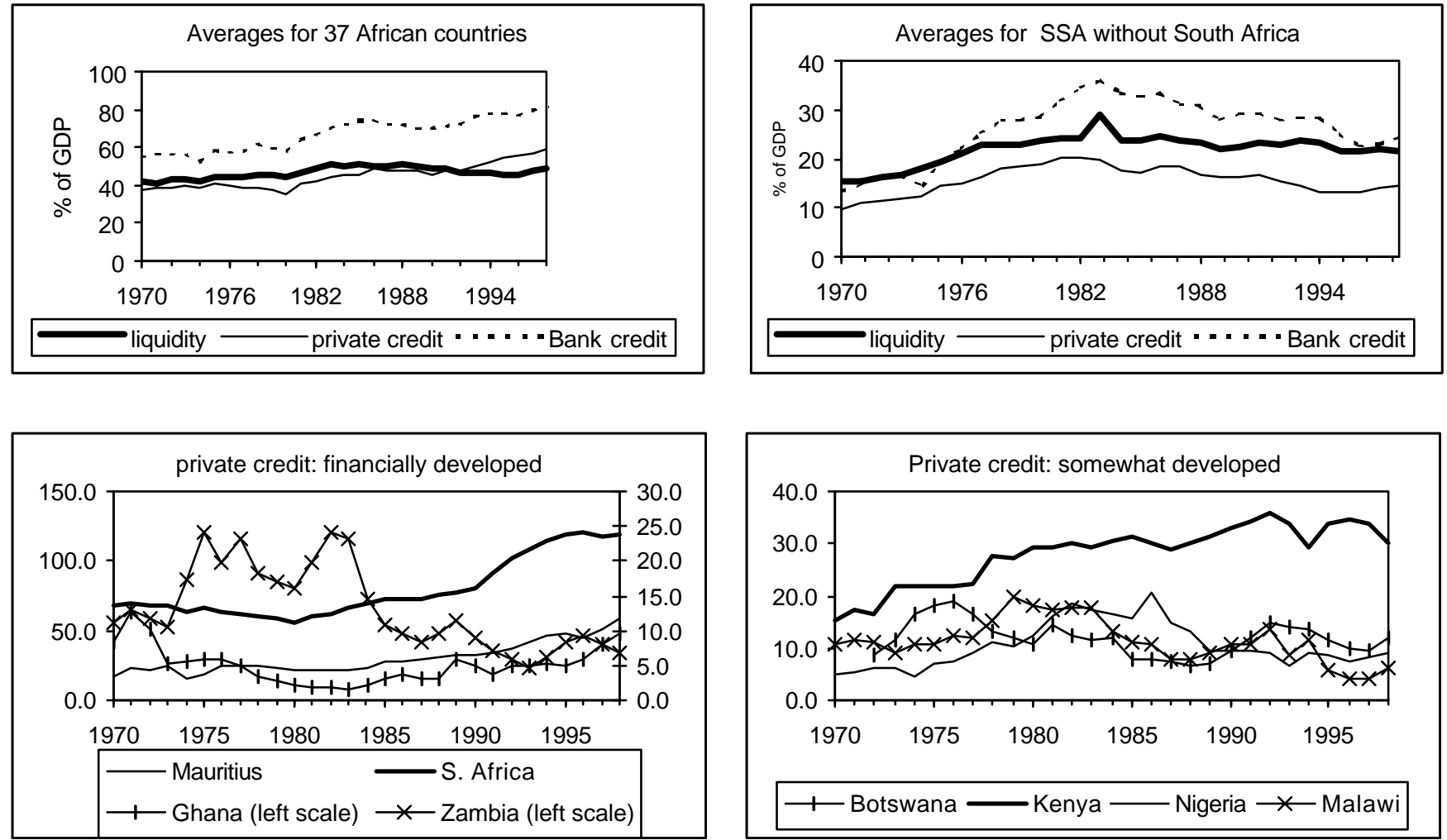

Source: World Development Indicators 2000; Gelbard and Leite (1999) "Measuring financial development in sub-Saharan Africa," IMF, working paper 99/105. Average aggregate ratios are for a sample of 37 countries, including 4 North African countries (Algeria, Egypt, Morocco, and Tunisia).

SSA = Sub-Saharan Africa.

"Liquidity" = liquid liabilities of financial institutions (M3 \% of GDP).

"Investment" = gross domestic investment (\% of GDP).

"Private credit" = credit to the private sector $(\%$ of GD). 
Figure 2: FDI inflows in some African countries, 1986-1999 (in million constant 1995 US\$)
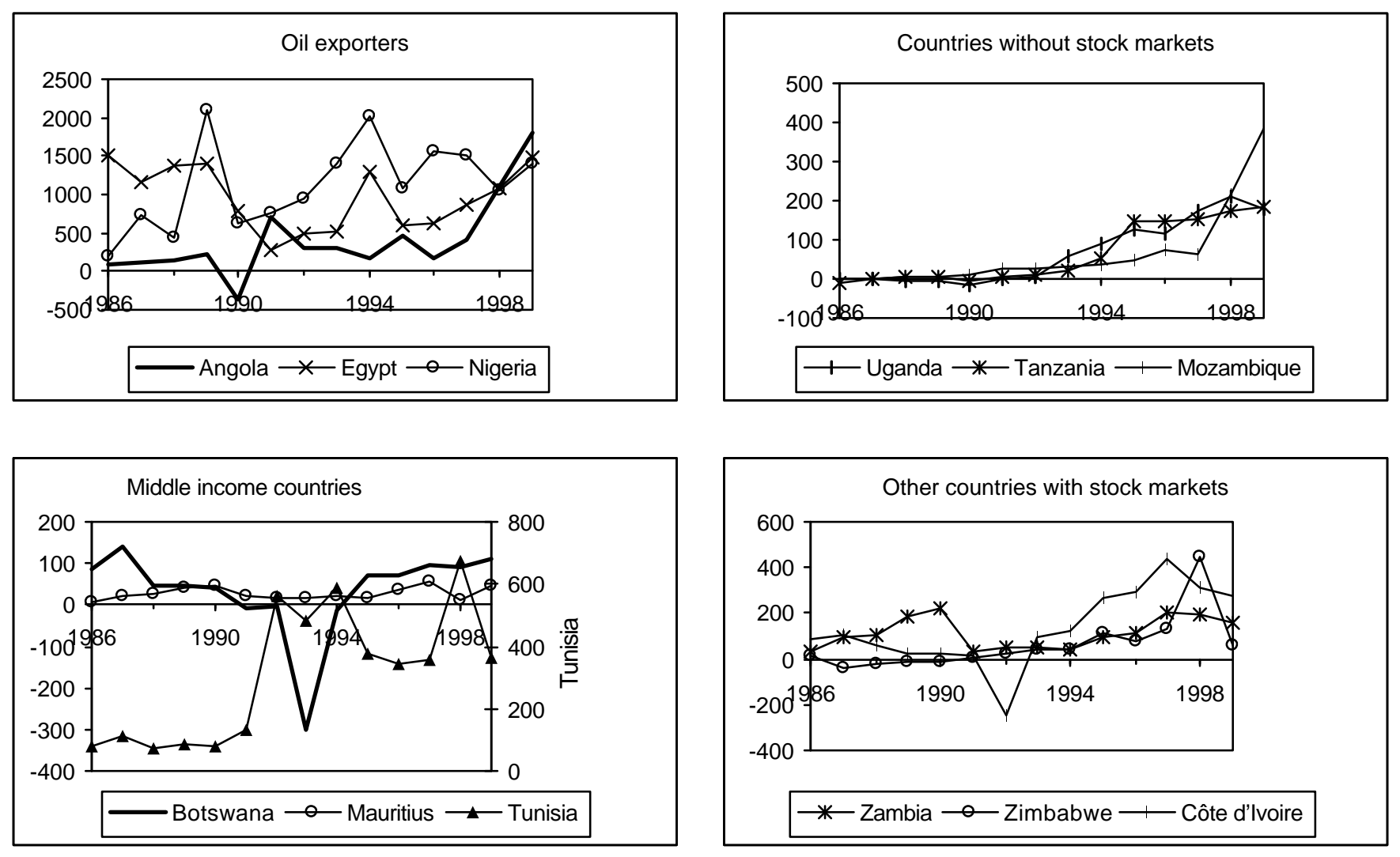

Source: UNCTAD, World Investment Report (various issues from 1992 to 2000).

Nomial values are deflated to real values using the US PPI index (base: 1995=100). 